\title{
THE ROLE OF FREE-RANGING MAMMALS IN THE DEPOSITION OF ESCHERICHIA COLI INTO A TEXAS FLOODPLAIN
}

\author{
A Dissertation \\ by \\ ISRAEL DAVID PARKER
}

\begin{abstract}
Submitted to the Office of Graduate Studies of Texas A\&M University

in partial fulfillment of the requirements for the degree of

DOCTOR OF PHILOSOPHY
\end{abstract}

August 2010

Major Subject: Wildlife and Fisheries Sciences 
The Role of Free-ranging Mammals in the Deposition of Escherichia coli into a Texas

\author{
Floodplain
}

Copyright 2010 Israel David Parker 


\title{
THE ROLE OF FREE-RANGING MAMMALS IN THE DEPOSITION OF ESCHERICHIA COLI INTO A TEXAS FLOODPLAIN
}

\author{
A Dissertation \\ by \\ ISRAEL DAVID PARKER \\ Submitted to the Office of Graduate Studies of \\ Texas A\&M University \\ in partial fulfillment of the requirements for the degree of \\ DOCTOR OF PHILOSOPHY
}

Approved by:

Chair of Committee, $\quad$ Roel R. Lopez

Committee Members, Donald S. Davis

James C. Cathey

Nova J. Silvy

Head of Department, Thomas E. Lacher, Jr.

August 2010

Major Subject: Wildlife and Fisheries Sciences 


\begin{abstract}
The Role of Free-ranging Mammals in the Deposition of Escherichia coli into a Texas Floodplain.

(August 2010)

Israel David Parker, B.S., New Mexico State University; M.S., Texas A\&M University

Chair of Advisory Committee: Dr. Roel R. Lopez
\end{abstract}

Free-ranging wildlife are an important contributor of fecal pollution in the form of Escherichia coli (E. coli) to water bodies. Currently, details of this contribution are nebulous and understudied. Much of the related research has not focused on freeranging wildlife; instead investigations examine entire systems while estimating wildlife contribution indirectly or with data of inconsistent quality and source. I began my research by conducting a meta-analysis of existing research to determine the current state of knowledge of wildlife's specific contribution. Data were sparse, fragmented, of variable quality, and difficult to access. Researchers relied on a variety of outside sources (e.g., state natural resource agencies). Making comparison between studies was nearly impossible because methodologies differed greatly or were described inconsistently. I then calculated wildlife population densities, undertook fecal collection, and conducted spatial analyses of fecal deposition to gather accurate and 
relevant data of the study area. I augmented field data collection with data derived from my meta-analysis (i.e., fecal deposition rates). I was able to estimate the relative role of individual species (e.g., raccoons [Procyon lotor], white-tailed deer [Odocoileus virginianus], and feral hogs [Sus scrofa]). Finally, I created a model using these data to determine important parameters for future research (e.g., fecal deposition rates) and simulate various management strategies. Although all parameters need more research focus, I found defecation rates were especially important but little researched. I found raccoons were the greatest determiner of potential E. coli load in the floodplain though adjustment of other parameters would greatly impact these findings. 


\section{DEDICATION}

For my loving and supportive wife Andrea: always there 


\section{ACKNOWLEDGEMENTS}

The breadth of acknowledgements for a project with this many moving parts is rather large. I extend sincere thanks to the landowners and ranch managers who allowed me onto their properties. Without them, I would have no dissertation. They demonstrated patience and understanding as I trekked through pastures and bottomlands for 2 solid years, dragging traps and equipment. They trusted me to capture and handle wildlife on their land, and for that, I am extremely grateful. A requirement for anonymity prevents me from naming the landowners, but they know who they are: thank

you. I also thank personnel at Texas Water Resources Institute (TWRI). Lucas Gregory, Kevin Wagner, Allen Berthold, and Dr. Muktar worked hard to find participant landowners and admirably organized and kept track of the entire project. Bravo guys! I would like to thank Dr. Karthikeyan. Thanks for helping me improve my understanding of water quality. Of course, I also thank Reema Padia for analyzing all of those samples efficiently and quickly. Good luck in your next endeavors. I greatly thank my technical assistants B.J. Harlow and Becky Owens for their hard work. You guys managed to keep good attitudes even in the Texas summer and your help was invaluable. I definitely need to thank Aaron Sumrall and his family. Without you guys, I wouldn't have any hog samples, period. It was a pleasure to work with you and I hope to again in the future. I also thank Logan Gallant for his excellent efforts in sorting through picture data and deer trapping. Thanks a lot for the help with a rather mind-numbing job. It is 
important to thank Billy Lambert of the Texas Parks and Wildlife Department for his help. Thanks for helping me get in contact with landowners. I cannot say enough good things about my committee. Drs. Lopez, Silvy, Cathey, and Davis, you guys have been simply wonderful. You guys were always available, always helpful, and always a handful. Special thanks to Dr. Lopez. I challenge someone to find a better advisor. After 7 years of being your graduate student, you have not fired me or hired someone to beat me up so your patience is amazing. I never wanted for insight, support (monetary or otherwise), or encouragement. No thesis or dissertation should overlook the amazing contribution of the Wildlife and Fisheries Sciences Department office staff. Special thanks are given to Vicki and Shirley, who have been here since I started and have pulled me out of the fire more than I care to admit. Thank you...seriously. Also, thank you Andrea. You sweated buckets in the field with me and kept me encouraged at home. I could not have done it without you. Finally, I thank U.S. Geological Survey, TWRI, Hispanic Leadership Program in Agriculture and Natural Resources, and Texas A\&M University for funding my research and myself. 
TABLE OF CONTENTS

Page

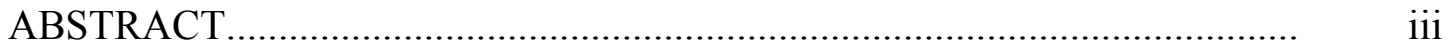

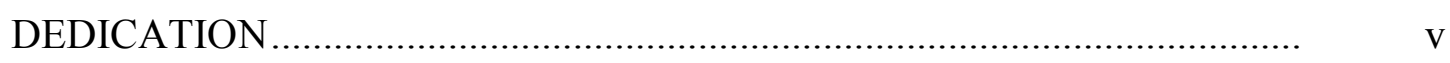

ACKNOWLEDGEMENTS.................................................................... vi

TABLE OF CONTENTS ........................................................................ viii

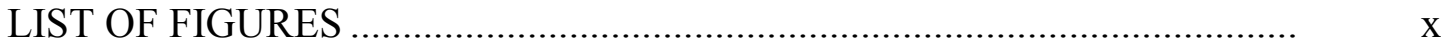

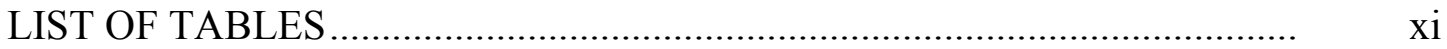

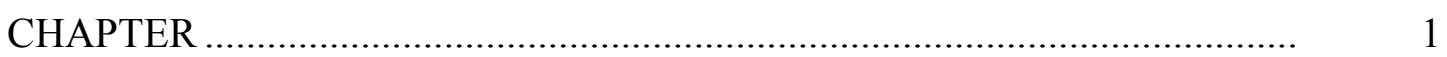

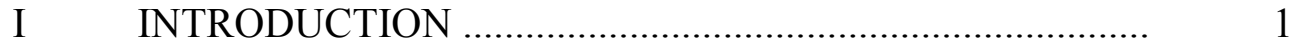

Background ............................................................. 1

Research Objectives ........................................................... 4

Study Area.....................................................................

II META-ANALYSIS OF THE ROLE OF FREERANGING WILDLIFE IN THE DEPOSITION OF ESCHERICHIA COLI INTO WATER BODIES .................. 8

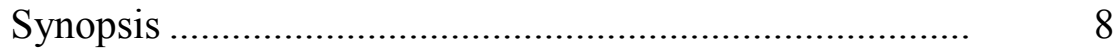

Introduction ................................................................ 9

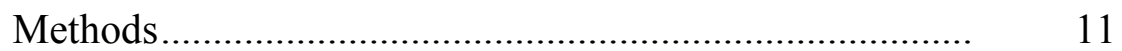

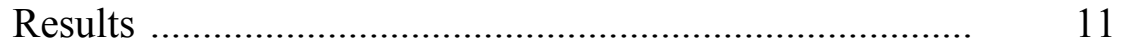

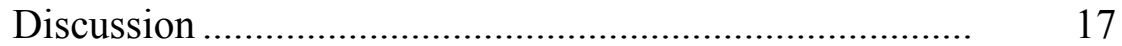

Conclusion ........................................................ 20 
III ROLE OF FREE-RANGING MAMMALS IN THE DEPOSITION OF ESCHERICHIA COLI INTO A

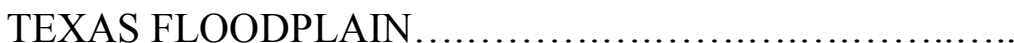

Synopsis

Introduction

Methods

Results

Discussion

Conclusion

IV A MODEL OF FREE-RANGING WILDLIFE CONTRIBUTION OF ESCHERICHIA COLI....

Synopsis

Introduction

Methods

Results

Discussion

Conclusion

V CONCLUSION AND IMPLICATIONS 


\section{LIST OF FIGURES}

FIGURE

Page

1.1 Location of Cedar Creek study area, Brazos County, Texas, 2008-2010

1.2 Location of research properties (Property A, Property B) on Cedar Creek and delineation of soil zones, Brazos County, Texas, 2008-2010

3.1 Representation of land use in the Cedar Creek watershed, Brazos County, Texas (U.S. Environmental Protection Agency 2010).......

3.2 Summary of estimated daily fecal deposit by species per $\mathrm{km}^{2}$, Cedar Creek, Brazos County, Texas, 2008-2009.

4.1 Diagram of STELLA model of $E$. coli deposition from freeranging wildlife in the Cedar Creek floodplain, Brazos County, Texas, 2008-2009.

4.2 Estimate of the impact of each parameter on overall E. coli load (subtraction of the mean E. coli loads found for the minimum parameter value from the maximum parameter value to determine the range of change) 


\section{LIST OF TABLES}

TABLE

Page

1.1 Index of important polluting animal species found in water quality studies, 2010 ....

2.1 Summary of research of wildlife contributions in impacting water quality by species, water quality measures, and population

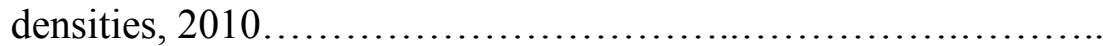

2.2 Listing of water quality research projects by species contributor

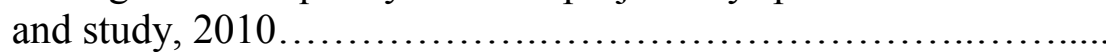

2.3 Comparison of mean E. coli concentration found in Parker data (Chapter III) to values found in the literature, Brazos County, Texas (2008-2009).

3.1 Compilation of density estimates for Property A and Property B, Brazos County, Texas 2008-2009.

3.2 Summary of $E$. coli concentrations in fecal material sampled from wildlife species, Brazos County, Texas, 2008-2009.

3.3 Estimated daily E. coli deposition by each study wildlife species, Brazos County, USA, 2009-2009 (conservative defecation rate $\mathrm{x}$ mean $E$. coli concentration x species density)..................

4.1 Low, medium, and high parameter estimates used in E. coli deposition analysis on Cedar Creek, Brazos County, Texas, 20082009.

4.2 Changes in potential E. coli load based on population density adjustments in Cedar Creek, Brazos County, Texas, 20082009 . 


\section{CHAPTER I}

\section{INTRODUCTION}

\section{BACKGROUND}

Water is at the center of many conflicts around the world. Examples date back to antiquity and extend from war in the Middle East to civil unrest in China and Pakistan to the second United States/Iraq war (Gleick 2006). Water issues take on a more polarized quality when they are combined with political and cultural mores (Haftendorn 2000).

These are often at play in the rural land ethic (e.g., agriculturally-based) versus urban value system. States like Texas that have a strong individualistic and agriculturalist tradition combined with growing urban populations often endure these conflicts. In the United States, many streams and rivers traverse both rural and urban areas, and pollution problems impact all water users along the length of the water body, though often to differing degrees. There is intense pressure to identify the pollution sources, thus leading to distrust between traditional land users (agriculturalists) and urban residents as livelihoods and cultural identities are tied to the results. The sources of water quality problems are often grouped into urban (human contributions) and rural (livestock and wildlife), though wildlife inhabits both. Many studies have found that depending on land use, all are potential contributors to water quality problems (Hagedorn et al. 1999, Atwill et al. 2003). It is obvious, then, that accurate source delineation is critically important.

This dissertation follows the style of the Journal of Wildlife Management. 
Escherichia coli (E. coli) and other fecal coliform species are so-called indicator species of water quality. It is assumed they are present mainly in warm-blooded species so their presence in a water body indicates fecal contamination and concomitant pathogens. Those water bodies that have fecal pollution loads above U.S.

Environmental Protection Agency standards are classified as impaired, thus necessitating comprehensive analysis of sources of fecal pollution and delineation of reductions necessary to return to compliance. Although, there is a wealth of independent water quality research, much of the data flows into and out of these source delineation studies, termed Total Maximum Daily Load (TMDL) plans.

The purpose of this dissertation is to characterize free-ranging mammals' contribution of $E$. coli into a Texas floodplain. Accurate data about the sources of fecal pollution into water bodies is vital in the creation of effective mitigation strategies. These sources vary based on location, land use, hydrology, and other factors. Previous E. coli research has investigated sources of fecal pollution in waterways, but little research had focused particularly on the role that free-ranging wildlife plays in water contamination (Brittingham et al. 1988, Dobson and Foufopolous 2001). The term wildlife is consistently defined as all non-domesticated animals that inhabit the study area in the following literature. Researchers have increasingly included free-ranging wildlife in their lists of non-point pollution sources. Generally, questions regarding wildlife have been incorporated into larger studies looking at all sources of pollution (Table 1.1). Little research has attempted to synthesize the information regarding 
Table 1.1. Index of important polluting animal species found in water quality studies, 2010.

\begin{tabular}{|c|c|}
\hline Common Name & Species Name \\
\hline White-tailed deer & Odocoileus virginianus \\
\hline Virginia opossum & Didelphis virginiana \\
\hline Striped skunk & Mephitis mephitis \\
\hline Nine-banded armadillo & Dasypus novemcinctus \\
\hline Raccoon & Procyon lotor \\
\hline Feral hog & Sus scrofa \\
\hline Eastern gray kangaroo & Macropus giganteus \\
\hline Wombat & Vombatus ursinus \\
\hline Pademelon & Halmaturus eugenii \\
\hline Swamp wallaby & Wallabia bicolor \\
\hline Brushtail possum & Trichosurus vulpecula \\
\hline Platypus & Ornithorhynchus anatinus \\
\hline Common brown antechinus & Antechinus stuartii \\
\hline Australian wood duck & Chenonetta jubata \\
\hline Bush rat & Rattus fuscipes \\
\hline Red fox & Vulpes vulpes \\
\hline European rabbit & Oryctolagus cuniculus \\
\hline Feral goat & Capra aegagrus \\
\hline Common carp & Cyprinus carpio \\
\hline Canada goose & Branta canadensis \\
\hline North American Beaver & Castor canadensis \\
\hline Wild Turkey & Maleagris gallopavo \\
\hline Bobcat & Lynx rufus \\
\hline Red-winged blackbird & Agelaius phoeniceus \\
\hline Coyote & Canis latrans \\
\hline Killdeer & Charadrius vociferus \\
\hline Roadrunner & Geococcyx californianus \\
\hline California ground squirrel & Spermophilus beecheyi \\
\hline Yellow-bellied marmot & Marmota flaviventris \\
\hline Boat-tailed grackle & Quiscalus major \\
\hline Ring-billed gull & Larus delawarensis \\
\hline Javelina & Tayassu pecari \\
\hline Moose & Alces alces \\
\hline European starling & Sturnus vulgaris \\
\hline Muskrat & Ondatra zibethicus \\
\hline Mallard & Anas platyrhynchos \\
\hline Domestic cat & Felis catus \\
\hline
\end{tabular}


wildlife and E. coli into a single document that compares existing research and important results.

\section{RESEARCH OBJECTIVES}

Objectives of my dissertation were to: (1) conduct a meta-analysis of water quality research (particularly focused on E. coli) that includes wildlife, (2) determine the role of wildlife in the deposition of $E$. coli into a Texas floodplain, and (3) create a model of wildlife E. coli deposition. My dissertation is divided into 3 primary chapters with each designed as an individual publication so some repetition between chapters is expected. Chapter titles are as follows:

1. A meta-analysis of the role of free-ranging wildlife in the deposition of Escherichia coli into water bodies (Chapter II)

2. The role of free-ranging mammals in the deposition of Escherichia coli into a texas floodplain (Chapter III)

3. A model of free-ranging wildlife deposition of Escherichia coli (Chapter IV)

\section{STUDY AREA}

I evaluated the role of wildlife in E. coli transmission in the Cedar Creek (Brazos County) watershed (Fig. 1.1). Brazos County is located in southeast Texas in the Post Oak Savannah ecoregion. Texas Parks and Wildlife Department (2010) describes the post oak savannah as

\footnotetext{
a savannah dominated by native bunch grasses and forbs with scattered clumps of trees, primarily post oaks [Quercus stellata]. Forested areas [are] generally restricted to bottomlands along major rivers and creeks, or in areas protected from fire...Sands and sandy loams are predominantly found on upland sites, while clay or clay loams are typically associated with bottomlands. A dense clay pan, that is almost impervious to water, underlies all soil types within the region at depths of only a few feet.
} 
Cedar Creek flows southeast for a total of approximately $44 \mathrm{~km}$ through Robertson County and the northern part of Brazos County before emptying into the Navasota River on the eastern border of Brazos County. The Navasota River ultimately merges with the Brazos River at the southern tip of the county. Cedar Creek has a history of impairment due to bacterial loads (U.S. Environmental Protection Agency 2008). I conducted my research on 2 private ranches (Property A, 518 ha; Property B, 660 ha) bisected by Cedar Creek (Fig. 1.1). Each ranch stocked cattle (Property A, 1 cow:10.36 ha; Property B, 1 cow:2.2 ha) on typical post oak savannah of mixed upland/bottomland grasslands with scattered post oak woodlands located both in the upland and bottomland zones. Both properties exhibited impacts from grazing, though Property B had shorter grasses and more impacted soils, likely due to higher cattle stocking rate. Each property had ample available water from Cedar Creek and numerous stock tanks located throughout the properties. Property B had several active oil wells with concomitant truck traffic and habitat alteration. Soils throughout the Cedar Creek floodplain were classified by Natural Resources Conservation Service according to probability of 1 annual overland water flow occurrence (flooding or rainfall; occasional $=5-50 \%$, frequent $=>50 \%$; Fig. 1.2). 


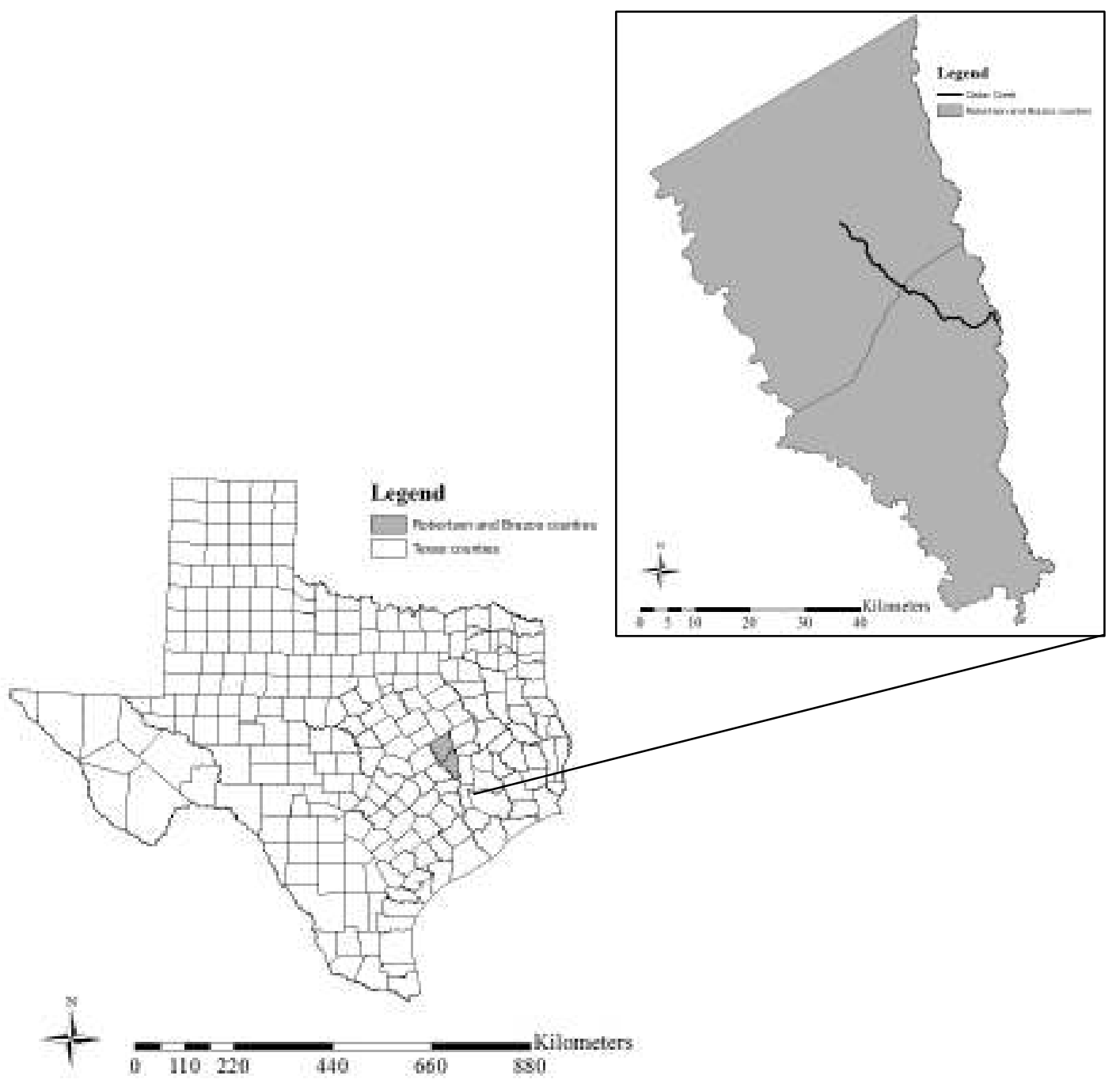

Figure 1.1. Location of Cedar Creek study area, Brazos County, Texas, 2008-2010. 


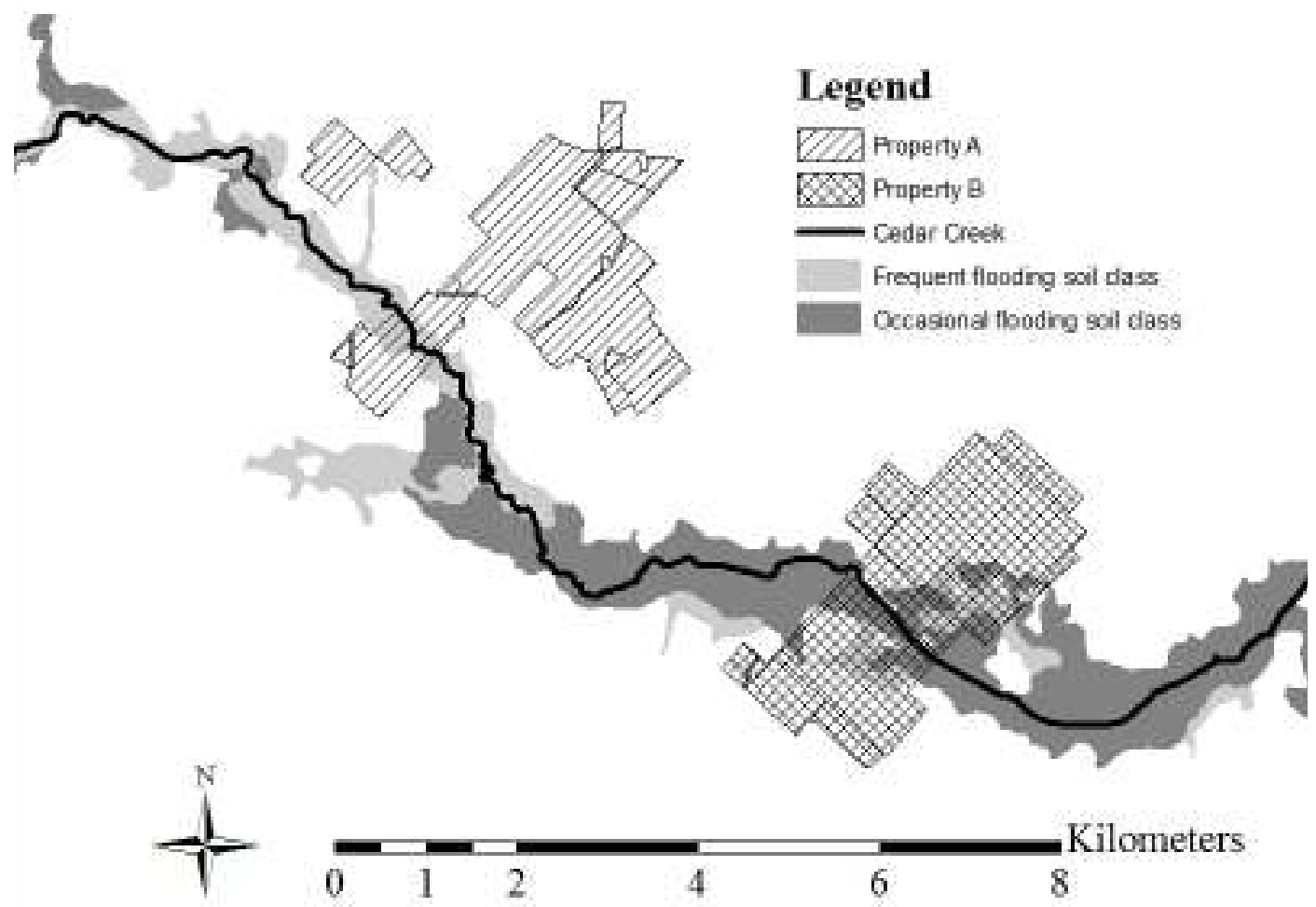

Figure 1.2. Location of research properties (Property A, Property B) on Cedar Creek and delineation of soil zones, Brazos County, Texas, 2008-2010. 


\section{CHAPTER II}

\section{META-ANALYSIS OF THE ROLE OF FREE-RANGING WILDLIFE IN THE DEPOSITION OF ESCHERICHIA COLI INTO WATER BODIES}

\section{SYNOPSIS}

Free-ranging wildlife are widely recognized as an important contributor of fecal pollution into water bodies. As state and federal agencies create plans to mitigate for point and non-point fecal pollution, the need for accurate data regarding all sources has increased. As part of that initiative, I conducted a meta-analysis focused on the nexus between wildlife and water quality in order to provide a relevant synthesis of data to land managers tasked with improving water quality. My objectives were to: (1) summarize reported mammalian species Escherichia coli (E. coli) contribution, and (2) identify gaps or inconsistencies in the literature. I used Google Scholar (Google, Mountain View, California) and the Texas A\&M University article search system that I configured to look into 9 separate databases. I included articles relating to both E. coli research specifically and fecal coliform analyses generally as they relate to wildlife or mammals. I then compared techniques and results in the literature to my own research on wildlife and water quality. Meta-analysis results suggest that water quality studies $(n=27)$ often used wildlife data (i.e., population density and fecal deposition rates), but the quality of the data varied greatly. Data were available in limited degrees, but difficult to evaluate, use, and compare between studies. For instance, different metrics of analysis (fecal coliform $=48 \%$ of studies, Escherichia coli $=41 \%$ of studies) were often used making comparison between studies difficult. Previous research found wildlife density increased 
the impact on wildlife contribution to water quality. However, the wildlife mass, behavior, and E. coli load also affected the size of the per species impact. The most numerous species did not necessarily have the most impact.

\section{INTRODUCTION}

Water quality concerns are growing throughout much of the world as anthropogenic impacts on the environment are coupling with increasing human need for water. Land managers and natural resource decision-makers need to understand the role of wildlife in the deposition of E. coli into watersheds in order to successfully manage water supplies in the state and to implement effective pollution control strategies. Furthermore, information concerning the contribution of $E$. coli from free-ranging wildlife populations is needed to improve watershed-level contamination models and reliability of model results. This will allow managers to develop alternative strategies for system management in order to meet water quality standards. Finally, understanding of water quality problems is needed for mitigation efforts mandated under the Clean Water Act (1972).

E. coli and other fecal coliform species are so-called indicator species of water quality. It is assumed that they are present mainly in warm-blooded species therefore their presence in a water body indicates fecal contamination and the concomitant risk for pathogens harmful to humans. Those water bodies that have fecal pollution loads above U.S. Environmental Protection Agency standards are classified as impaired, thus necessitating the comprehensive analysis of sources of fecal pollution and reductions necessary to return to compliance. Although, there is a wealth of independent water 
quality research, significant quantities of the data flows into and out of these source delineation studies, termed Total Maximum Daily Load (TMDL) plans.

Previous E. coli research has investigated sources of fecal pollution in waterways, but little research had focused particularly on the role that free-ranging wildlife play in water contamination (Brittingham et al. 1988, Dobson and Foufopolous 2001). The term wildlife is consistently defined as all non-domesticated animals that inhabit the study area. Researchers have increasingly included free-ranging wildlife in their lists of non-point pollution sources. Generally, questions regarding wildlife have been incorporated into larger studies examining all sources of pollution. The term wildlife though, has varied from study to study due to availability of data or perceptions of researchers towards wildlife impact. The wildlife data in pollution studies vary in scope, methodology, and aim. However, little research has been attempted to coalesce the information regarding wildlife and E. coli into a single document that compares existing research and important results. Hedges et al. (1999) defined meta-analysis as the formal application of quantitative methods to summarize evidence across studies. Meta-analysis then has the potential dramatically change this fragmented paradigm into a synthesized whole (Gurevitch et al. 1992). Such a synthesis provides a platform from which to develop general theory (Arnqvist and Wooster 1995).

The goal of this meta-analysis was to describe existing research concerning wildlife and water quality, particularly E. coli. My objectives were to: (1) summarize reported wildlife species $E$. coli contribution and (2) identify gaps or inconsistencies in the literature. 


\section{METHODS}

I conducted this meta-analysis using Google Scholar (Google, Mountain View, California) and the Texas A\&M University article search system that I configured to look into 10 separate databases. These databases included the following: Academic Search Complete, Business Source Complete, CAB Abstracts, ERIC, MEDLINE, MLA International Bibliography, OmniFile FT Mega, PsycINFO 1872-current, ScienceDirect, and Web of Science. I included articles relating to both E. coli research specifically and fecal coliform analyses generally. I gathered data on E. coli concentrations in feces and E. coli deposition when available. I also gathered data sets especially important for wildlife managers (i.e., species, wildlife population densities, fecal deposition rates). I then conducted a 2-tier analysis: (1) determination of important trends in data from literature, and (2) illumination of patterns in the methods and presentation of water quality research in regards to wildlife. I included my research conducted in the Cedar Creek watershed in central Texas (2008-2009) for comparison (Chapter III).

\section{RESULTS}

Wildlife were acknowledged as important contributors of fecal pollution.

Animals, in one form or another, are present in all watersheds and a variety of research has demonstrated that a large portion of their fecal material is washed into water bodies. I found water quality research uneven in the analysis of the impact of wildlife (Table 2.1). My sample of studies indicated little standardization in wildlife analyses and little data geared towards aiding natural resource managers. 
A relative paucity of rigorous data prevented a full meta-analysis. None of the studies included all of the necessary components (sample size, standard deviation, mean, and well-described methodology) to conduct a meta-analysis as described by Hedges et al. (1999). I, therefore, restricted this meta-analysis to (1) descriptive statistics, and (2) comparison of means for $E$. coli concentration and deposition.

I reviewed 27 water quality studies that incorporated wildlife of some sort into their framework (Table 2.2). Approximately $74 \%$ found deer important $(n=20)$, equaled by waterfowl/shorebirds $(74 \%, n=20)$, and followed by raccoons $(52 \%, n=$ 14), muskrats $(33 \%, n=9)$, turkeys $(30 \%, n=8)$, opossums $(26 \%, n=7)$, hogs $(15 \%, n$ $=4)$, and various other species $(67 \%, n=18)$. Waterfowl and shorebirds were researched by many of the studies, but to varying degrees. Some studies examined only geese (presumably Canada geese [Branta canadensis]), though others looked at mallards [Anas platyrhynchos], wood ducks [Aix sponsa], and others. The group labeled "Other" was comprised of all other species. These were generally in less than $10 \%$ of the studies (e.g., javelina [Tayassu pecari]), though beavers [Castor canadensis] were in $6(22 \%)$. As a whole, infrequently studied species occurred in about $67 \%$ of all of the studies, thus indicating the importance of regionally specific species and the difficult task of researchers determining species to include.

I found that sample studies used different indicator organism classifications. Researchers used either the general fecal coliform indicator or the more specific E. coli indicator in $48 \%(n=13)$ and $41 \%(n=11)$ of studies, respectively (3 studies used neither). Interestingly, those studies that incorporated wildlife density $(37 \%, n=10)$ 
generally obtained information from non-peer-reviewed sources such as state natural resource agencies reports $(33 \%, n=9)$. A non-peer-reviewed source is any source that did not undergo rigorous peer-review prior to publishing or acceptance. Only 7 studies $(26 \%)$ incorporated any information about fecal deposition rates.

I collected insufficient data to conduct comparison of means; however, I found much lower E. coli concentrations in white-tailed deer and raccoons than indicated in other studies (Table 2.3). The main problem was the dearth of studies that comprehensively included wildlife into water pollution studies, leaving far too few to conduct significance testing.

Many of the studies were based on water sampling rather than direct sampling from wildlife; therefore obviating the need for wildlife density estimates. However, of the studies that incorporated some kind of density estimation, $90 \%$ of those estimates were taken from non-peer-reviewed research. 
Table 2.1. Summary of research of wildlife contributions in impacting water quality by species, water quality measures, and population densities, 2010.

\begin{tabular}{|c|c|c|c|c|c|}
\hline Species & $\begin{array}{l}\mathrm{CFU} / \mathrm{g} \text { of } \\
\text { fecal material }\end{array}$ & $\begin{array}{l}\text { Fecal } \\
\text { deposit } \\
\text { g/day }{ }^{\mathrm{a}}\end{array}$ & $\begin{array}{l}\text { CFU/day/ } \\
\text { head }\end{array}$ & $\begin{array}{l}\text { Pop. } \\
\text { density } \\
\left(\# / \mathrm{km}^{2}\right)^{\mathrm{b}}\end{array}$ & Study \\
\hline \multirow[t]{9}{*}{ Deer } & $2.2 \times 10^{6}(\mathrm{FC})$ & - & - & - & Cox et al. 2005 \\
\hline & 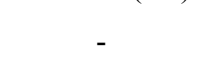 & - & $\begin{array}{l}1.75 \times 10^{8} \\
(\mathrm{EC})\end{array}$ & - & Teague et al. 2009 \\
\hline & $10^{7}(\mathrm{EC})$ & 310 & - & 7.06 & Rice 2005 \\
\hline & $3.8 \times 10^{5}(\mathrm{FC})$ & $772 *$ & - & 20.76 & Maptech 2002 \\
\hline & 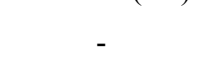 & - & $\begin{array}{l}7.72 \times 10^{9} \\
\quad(\mathrm{FC})\end{array}$ & $\begin{array}{c}12.36- \\
17.38\end{array}$ & Culver et al. 2002 \\
\hline & $4.5 \times 10^{5}(\mathrm{FC})$ & $772 *$ & $\begin{array}{l}3.47 \times 10^{8} \\
\quad(\mathrm{FC})\end{array}$ & 11.90 & Lawson 2001 \\
\hline & $10^{6}(\mathrm{EC})$ & - & - & 7.72 & $\begin{array}{l}\text { Wittman Hydro Planning } \\
\text { Associates, Inc. } 2004\end{array}$ \\
\hline & - & - & $\begin{array}{l}3.47 \times 10^{8} \\
\quad(\mathrm{FC})\end{array}$ & - & Brannan et al. 2001 \\
\hline & - & - & $\begin{array}{l}5.00 \times 10^{8} \\
(\mathrm{EC})\end{array}$ & 4.94 & Wieckowicz et al. 2008 \\
\hline \multirow[t]{4}{*}{ Hogs } & $4.1 \times 10^{4}(\mathrm{FC})$ & - & - & - & Cox et al. 2005 \\
\hline & - & - & - & $3.6-4.7$ & Kaller et al. 2007 \\
\hline & - & - & $\begin{array}{l}2.23 \times 10^{9} \\
\quad(\mathrm{EC})\end{array}$ & $3.2-6$ & Teague et al. 2009 \\
\hline & - & - & $\begin{array}{c}1.08 \mathrm{x} \\
10^{10}(\mathrm{EC})\end{array}$ & - & Wieckowicz et al. 2008 \\
\hline \multirow[t]{8}{*}{ Raccoons } & $10^{7}(\mathrm{EC})$ & 280 & - & 12.36 & Rice 2005 \\
\hline & $2.1 \times 10^{6}(\mathrm{FC})$ & $450 *$ & - & 17.30 & Maptech 2002 \\
\hline & 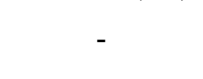 & - & $\begin{array}{l}1.13 \times 10^{8} \\
\quad(\mathrm{FC})\end{array}$ & - & Brannan et al. 2001 \\
\hline & - & - & $\begin{array}{l}8.14 \times 10^{8} \\
(\mathrm{FC})\end{array}$ & 17.38 & Culver et al. 2002 \\
\hline & $10^{6}(\mathrm{EC})$ & - & 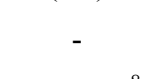 & 12.36 & $\begin{array}{l}\text { Wittman Hydro Planning } \\
\text { Associates, Inc. } 2004\end{array}$ \\
\hline & $2.5 \times 10^{5}(\mathrm{FC})$ & $450 *$ & $\begin{array}{l}1.13 \times 10^{8} \\
(\mathrm{FC})\end{array}$ & 19.01 & Lawson 2001 \\
\hline & - & - & - & - & Millican and Hauck 2008 \\
\hline & - & - & $\begin{array}{l}1.25 \times 10^{8} \\
(\mathrm{EC})\end{array}$ & - & Wieckowicz et al. 2008 \\
\hline \multirow[t]{2}{*}{ Opossums } & $10^{7}(\mathrm{EC})$ & 140 & - & 1.74 & Rice 2005 \\
\hline & - & 17.5 & - & - & Porter et al. 2001 \\
\hline
\end{tabular}

${ }^{\mathrm{a}}$ Conservative estimates from literature (Chapter II)

${ }^{\mathrm{b}}$ Seasonal density ranges on 2 study properties (Chapter II) 
Table 2.2. Listing of water quality research projects by species contributor and study, 2010.

\begin{tabular}{|c|c|}
\hline Publications & Species* \\
\hline Cox et al. 2005 & $\begin{array}{l}\text { eastern gray kangaroo, wombat, pademelon, swamp wallaby, } \\
\text { brushtail possum, platypus, common brown antechinus, Australian } \\
\text { wood duck, bush rat, feral hog, red fox, European rabbit, feral goat, } \\
\text { white-tailed deer, common carp, domestic cat }\end{array}$ \\
\hline Teague et al. 2009 & white-tailed deer, feral hog \\
\hline Rice 2005 & white-tailed deer, raccoon, rabbit, geese, Virginia opossum, \\
\hline MapTech, Inc. 2002 & white-tailed deer, raccoon, geese, muskrat, turkey, beaver, mallard \\
\hline Culver et al. 2002 & white-tailed deer, raccoon, Canada goose, muskrat, beaver \\
\hline Lawson et al. 2002 & white-tailed deer, raccoon, geese, muskrat, beaver, duck \\
\hline Wittman Hydro Planning & white-tailed deer, raccoon, rabbit, Canada goose, Virginia opossum, \\
\hline Associates, Inc. 2004 & turkey, mice, squirrel, coyote \\
\hline Wieckowicz et al. 2008 & $\begin{array}{l}\text { white-tailed deer, geese, muskrat, wild turkey, beaver, duck, } \\
\text { waterfowl }\end{array}$ \\
\hline Kaller et al. 2007 & feral hog \\
\hline Millican and Hauck 2008 & $\begin{array}{l}\text { white-tailed deer, raccoon, rabbit, Virginia opossum, armadillo, mice, } \\
\text { squirrel, bobcat, rat, waterfowl, heron, grackle, egret, kingbird, } \\
\text { sparrow, dove, red-winged blackbird, flycatcher, starling, vulture, } \\
\text { killdeer, seagull, roadrunner, guinea }\end{array}$ \\
\hline Porter et al. 2001 & Virginia opossum \\
\hline Atwill et al. 2003 & $\begin{array}{l}\text { striped skunk, California ground squirrels, coyotes, yellow-bellied } \\
\text { marmot }\end{array}$ \\
\hline Booth et al. 2003 & white-tailed deer, raccoon, geese, muskrat, wild turkey, duck, coyote \\
\hline Guan et al. 2002 & white-tailed deer, geese, moose, turkey \\
\hline Meyer et al. 2005 & geese \\
\hline Whitlock et al. 2002 & $\begin{array}{l}\text { raccoon, Virginia opossum, gallinule, coot, duck, European starling, } \\
\text { boat-tailed grackle }\end{array}$ \\
\hline Levesque et al. 1993 & ring-billed gull \\
\hline Hagedorn et al. 1999 & white-tailed deer, waterfowl \\
\hline Casarez et al. 2007 & $\begin{array}{l}\text { white-tailed deer, raccoon, rabbit, geese, Virginia opossum, } \\
\text { armadillo, feral hog, skunk, javelina, pigeon, grackle, waterfowl }\end{array}$ \\
\hline Hamilton et al. 2006 & white-tailed deer, Canada goose, duck \\
\hline Ram et al. 2007 & raccoon \\
\hline Siewicki et al. 2007 & white-tailed deer, raccoon, shorebirds, gull, waterfowl, pigeon \\
\hline Somarelli et al. 2007 & white-tailed deer, Canada goose, \\
\hline Maryland Dept. of the & white-tailed deer, raccoon, geese, muskrat, wild turkey, beaver, duck \\
\hline Environment 2005 & \\
\hline Miller 2004 & white-tailed deer, Virginia opossum, squirrel, muskrat, birds \\
\hline Maryland Dept. of the & white-tailed deer, raccoon, geese, muskrat, wild turkey, beaver, duck \\
\hline Environment 2004 & \\
\hline Zeckoski et al. 2005 & white-tailed deer, raccoon, geese, muskrat, turkey, beaver, duck \\
\hline
\end{tabular}

${ }^{\mathrm{a}}$ Aside from 3 exceptions, wildlife were named as they were listed in publication. I included specific species names for white-tailed deer, feral hogs, Virginia opossum when listed as deer, hogs or pigs, and opossum, respectively. Wildlife with no specific name (e.g., duck, geese) had no additional information. 
Table 2.3. Comparison of mean E. coli concentration found in Parker data (Chapter III) to values found in the literature, Brazos County, Texas (2008-2009).

\begin{tabular}{|c|c|c|c|}
\hline Species & $\begin{array}{l}\text { E. coli } \mathrm{CFU} / \mathrm{g} \text { of } \\
\text { fecal material }(\overline{\mathrm{x}})\end{array}$ & $n$ & $\begin{array}{l}\text { Number of } \\
\text { Studies }\end{array}$ \\
\hline \multicolumn{4}{|l|}{ Parker data } \\
\hline $\begin{array}{l}\text { White-tailed } \\
\text { deer }\end{array}$ & $2.89 \times 10^{5}$ & 10 & 1 \\
\hline Feral hog & $5.63 \times 10^{6}$ & 45 & 1 \\
\hline $\begin{array}{l}\text { Virginia } \\
\text { opossum }\end{array}$ & $1.60 \times 10^{7}$ & 88 & 1 \\
\hline Raccoon & $1.59 \times 10^{7}$ & 177 & 1 \\
\hline \multicolumn{4}{|l|}{ Literature data } \\
\hline $\begin{array}{l}\text { White-tailed } \\
\text { deer }\end{array}$ & $5.5 \times 10^{6}$ & - & 2 \\
\hline Feral hog & - & - & 1 \\
\hline $\begin{array}{l}\text { Virginia } \\
\text { opossum }\end{array}$ & $1.0 \times 10^{7}$ & - & 1 \\
\hline Raccoon & $5.5 \times 10^{6}$ & - & 2 \\
\hline
\end{tabular}

${ }^{\mathrm{a} O b t a i n e d ~ f r o m ~ l i t e r a t u r e ~ e s t i m a t e s ~}$ 


\section{DISCUSSION}

Much of the water quality research I found was variable in scope, methodology, and interpretations. It was inconsistent in use of $E$. coli versus the general fecal coliform indicators and in presentation of results (e.g., determination of species density, fecal deposition rates, overall contribution of wildlife to fecal load in the watershed). Confounding methodologies and results of existing research likely hinder integration of water quality research into natural resource management. Accurate and precise research allows managers to adjust strategies to confront the increasing challenges of growing human populations, pollution, invasive species, etc. (Kennedy and Thomas 1995, Kellert 1996, McKinney 2002). Much of the sampled water quality research, however, was not geared towards natural resource managers who are often the people tasked with making the changes necessary to improve water quality. In order to maximize the potential usefulness of water quality research, a clear relationship between wildlife and impact must be described. This requires detailed descriptions of wildlife population estimation, wildlife sampling techniques, and sources of data. Only then can managers make informed decisions about wildlife population management. In my research, I provided data pertinent to the natural resource manager in usable terms. I used proven capturerecapture and capture-resight methodologies to determine mammal densities. I collected fecal samples directly from captured species and conducted transects to determine spatial characteristics of fecal deposition. The literature provided fecal deposition rates. Together, these data illuminated the important mammal species in the deposition of $E$. coli into the study floodplain. These data provided a clear relationship between species 
density and $E$. coli deposition with numbers that could be used in wildlife management for water quality improvement. Environmental systems are already dauntingly complex and my research could provide an important source of data not readily available to most natural resource managers (Naiman 1988, Dewulf et al. 2005).

Many water quality studies suffer from several difficulties. Water quality researchers rely on existing data to determine wildlife densities and per capita pollution impacts when creating models or designing management strategies. Research is often limited by data and expertise available. For water quality researchers, the only sources of regionally relevant wildlife population data and behavior are state natural resource agencies and extension agencies, and more rarely, academic institutions and published studies. These sources often use differing methodologies in different habitat types, thus increasing the difficulty in comparing results. Many studies likewise must get daily defecation rates (g/day) from a variety of sources.

Although most wildlife data in water quality studies originated from state natural resource agencies, the methodology used to attain density estimates varied significantly. For instance, Parajuli et al. (2008) evaluated the effects of best management practices (efforts to reduce pollution movement into the water body) on water quality and relied on summer roadkill indices and expert opinions to determine wildlife densities. Kaller et al. (2007) compared water quality in watersheds to determine the impact of feral hogs. They relied on harvest data to determine population trends. In their model of microbial contaminants from grazed fields, Tian et al. (2002) used stock units that covered expected wildlife contribution without getting wildlife data. 
Although some studies looked at a variety of species (Culver et al. 2002, Teague et al. 2009), others were more limited in scope, such as the impacts of white-tailed deer and geese on water quality in New York (Somarelli et al. 2007), white-tailed deer in South Carolina (Miller 2004), or the broad impacts of feral hogs on water quality in Louisiana (Kaller et al. 2007). All of these species are technically wildlife; however, the representative suite is dependent on the data and research time available and the researchers' professional opinions on which species are important. This limits the number of comprehensive studies or coordinated efforts towards improving water quality, further restricting the data available to managers.

An important question from a wildlife management perspective is the correlation between wildlife species density and water quality impact. For the land manager tasked with understanding water quality issues and with carrying out mitigation strategies, a connection between number of animals in the watershed and fecal pollution contribution is important. Wildlife surveys are part of the stock and trade of many land managers and represent a key tool in improving water quality.

Natural resource managers have learned the hard way to only create management plans with sufficient knowledge of the system. Incoherent or poorly thought-out strategies often create more problems than they solve (Morrison 2002). Water quality plans, similarly, require detailed knowledge of the local fauna, their contributions to water quality, and their role in the ecosystem. Authors of several of the TMDLs mentioned in this review were careful to include statements that clearly stated they were not advocating reducing wildlife in order to meet water quality standards, 
even if wildlife were found to be a major contributor. Elucidating the connection between species, species density/population size, and impact on water quality are clear cues that wildlife managers can incorporate into management plans. The population size-pollution relationship also can provide cues for management. For instance, if water quality tests find that a certain over-abundant species is contributing an inordinate amount of fecal material to a water body then the solution seems obvious. If a species of large density has a small individual impact, but a large collective impact, then control of the species may not be practical. Managers also must understand the balance of the ecosystem, including species' densities/population sizes to understand the impact of changing those population numbers (Naiman 1988).

\section{CONCLUSION}

Previous research found wildlife density was a large impactor on wildlife contribution to water quality. Water quality studies often used wildlife data (i.e., population density and fecal deposition rates), but the quality of the data varied greatly. The data was available in limited degrees, but difficult to evaluate, use, and compare between studies. Although, species density is often reported in the water quality studies, I demonstrated that it is not consistently calculated or applied. Species density is a useful tool in aiding natural resource managers in mitigating wildlife impacts on water quality. Water quality research that incorporates accurate wildlife data such as population density/size provides a much more comprehensive and informative outlook for management plans. It is incumbent upon water quality studies to describe methodology for determining wildlife population parameters to allow these data to be 
applied across different studies more easily and accurately. Additionally, much could be done to increase the reliability of wildlife data, such as contracting out wildlife components of water quality research to wildlife professionals or consulting with natural resource agencies to ensure that data used are reliable and applicable to the study area. Ultimately, management recommendations must be carried out by managers. They require timely, accurate, and understandable information in order to make the best decisions. 


\section{CHAPTER III}

\section{ROLE OF FREE-RANGING MAMMALS IN THE DEPOSITION OF ESCHERICHIA COLI INTO A TEXAS FLOODPLAIN}

\section{SYNOPSIS}

The role of wildlife in the deposition of Escherichia coli (E. coli) is not well understood. Although water quality studies incorporate wildlife data, it often lacks a clear connection between wildlife density and E. coli deposition. Minimal understanding of species-specific fecal pollution and the role of species density on water quality complicates attempts by natural resource managers to reduce wildlife population sizes to improve water quality. My goal for this research was to determine the impact of free-ranging mammals (in general and species-specific) on E. coli loads in a floodplain. Objectives of this research were to determine the density of important free-ranging wildlife in the study area, research fecal deposition rates, and determine fecal E. coli loads for each species. I conducted a comprehensive literature review to determine fecal deposition rates for important mammals. I conducted mark-recapture and mark-resight populations density estimates (2008-2009) for meso- and large mammals in the study areas. I collected 338 fecal samples from study species (raccoon, $n=177$ samples, Virginia opossum, $n=88$ samples, white-tailed deer, $n=10$ samples, feral hog, $n=45$ samples, nine-banded armadillo, $n=7$, striped skunk, $n=11$ ) for E. coli analysis at a Biological and Agricultural Engineering laboratory at Texas A\&M University (College Station, Texas, USA). Finally, I walked 375 transects to determine spatial distribution of fecal material. I found that raccoons (Procyon lotor) provided the most E. coli into the 
floodplain followed by feral hogs (Sus scrofa), Virginia opossum (Didelphis virginiana), and white-tailed deer (Odocoileus virginianus) as the next important contributors. As a highly destructive invasive exotic species, feral hogs are the natural choice for intensive management. White-tailed deer are already highly managed in Texas. As arguably the most important game species in the state, population reduction is generally undesired; however, reduction of deer numbers would be advisable in certain situations (e.g., overpopulation). Meso-mammals populations can be controlled, but high effort, cost, and potential impact on ecosystem function make it difficult.

Management of habitat is critical to wildlife and water quality. For instance, cattle grazing strategies impact vegetative communities which impact overland water flow and species occurrence. Additionally, other point and non-point sources must be addressed first or in conjunction with wildlife management and the greater impacts on the ecosystem must be taken into account.

\section{INTRODUCTION}

Escherichia coli (E. coli) is a group of enteric bacteria symbiotic with warmblooded animal species. Current U.S. Environmental Protection Agency standards depend upon E. coli content as a determinant of fecal contamination into water bodies. These determinations can be complicated by nebulous understanding of wildlife contributions of $E$. coli. This is especially important as fecal material infected with $E$. coli is becoming a more common contaminant of watersheds used by humans for food, irrigation, drinking water, and recreation (Fisher et al. 2000, Mallin et al. 2000). Previous studies have demonstrated that $E$. coli has a variety of potential sources 
including city effluent and agricultural operations (Hagedorn et al. 1999, Booth et al. 2003).

Although previous $E$. coli research has investigated the role of traditional sources of fecal pollution, little research has investigated the role that free-ranging wildlife plays in water contamination (Brittingham et al. 1988, Dobson and Foufopolous 2001). Further studies are needed to understand the role of free-ranging wildlife populations in the deposition of $E$. coli in order to accurately describe the sources of fecal contamination (Renter et al. 2001, Solomon et al. 2001). Few studies have attempted to determine the important species in the watershed, provide density estimates of those species, and comprehensively collect fecal samples from them. Land managers and natural resource decision-makers need to understand the role of wildlife in the deposition of $E$. coli into Texas watersheds in order to successfully manage water supplies in the state and to implement effective pollution management strategies. Furthermore, information concerning the contribution of $E$. coli from free-ranging wildlife populations is needed to improve watershed-level contamination models and reliability of model results.

Many studies now use microbial source tracking to identify fecal polluters; however, these methods require a regionally specific bacteria source library. They also, often, rely on other sources for species density estimation (e.g., Culver et al. 2002) that may not describe the watershed under study. Microbial source tracking may be the way of future water quality assessment; however, site-specific wildlife density estimation and fecal collection from important local species will remain an important component in 
water policy. A meta-analysis of existing water quality research (Chapter I)

demonstrated that wildlife are important contributors to $E$. coli and fecal coliform loads found in impaired streams and so warrant the attention.

My study objectives were to identify, characterize, and quantify E. coli deposition from free-ranging wildlife populations into a floodplain of an impaired water body. This project clarified the spatial distribution of fecal sources, subsequent fecal deposition, and E. coli locations. Target species are exclusively mammalian (medium to large; e.g., Virginia opossum [Didelphis virginana], raccoons [Procyon lotor], whitetailed deer [Odocoileus virginianus], feral hogs [Sus scrofa]). Specific objectives were as follows: (1) Identify and estimate population densities of major wildlife contributors of fecal material in the study floodplain. Focal species were limited to those in direct contact to water course. (2) Evaluate the E. coli levels in fecal samples from identified major wildlife contributors. (3) Estimate the approximate amount of fecal material deposited by major contributors into the watershed on a daily basis.

\section{METHODS}

\section{Study Area}

I evaluated the role of wildlife in E. coli transmission in the Cedar Creek watershed (Brazos County; Fig. 3.1). Brazos County is located in southeast Texas in the Post Oak Savannah ecotone. Cedar Creek flows southeast for a total of approximately $44 \mathrm{~km}$ through Robertson County and the northern part of Brazos County before emptying into the Navasota River on the eastern border of Brazos County. The Navasota River ultimately merges with the Brazos River at the southern tip of the 
county. Cedar Creek has a history of impairment due to bacterial loads (U.S.

Environmental Protection Agency 2008). I conducted my research on 2 private ranches (Property A, 518 ha; Property B, 660 ha) bisected by Cedar Creek. Each ranch stocked cattle (Property A, 1 cow:10.36 ha; Property B, 1 cow:2.2 ha) on typical post oak savannah habitat of mixed upland/bottomland grasslands with scattered post oak woodlands located both in the upland and bottomland zones. Both properties exhibited impacts from grazing, though Property B had shorter grasses and more impacted soils likely due to higher cattle stocking rate. Each property had ample available water from Cedar Creek and numerous stock tanks located throughout the properties. Property B had several active oil wells with concomitant truck traffic and habitat alteration.

\section{Species Densities}

I used remotely-activated infrared triggered cameras (Non Typical, Inc., Park Falls, Wisconsin, USA) to determine densities of mammals present within the Cedar Creek floodplain (Trolle 2003, Acevedo et al. 2006). I selected 30 grid-based points on Property A (1 camera/14.3 ha; cameras not allowed on Property B) to place remotelyoperated infrared digital cameras for 25-50 consecutive days once during the winter, summer, and fall seasons (winter, 22 December-21 March; summer, 22 June-21

September; fall, 22 September-December 21) for the 2 year study (Jacobson et al. 1997, Watts et al. 2008). 


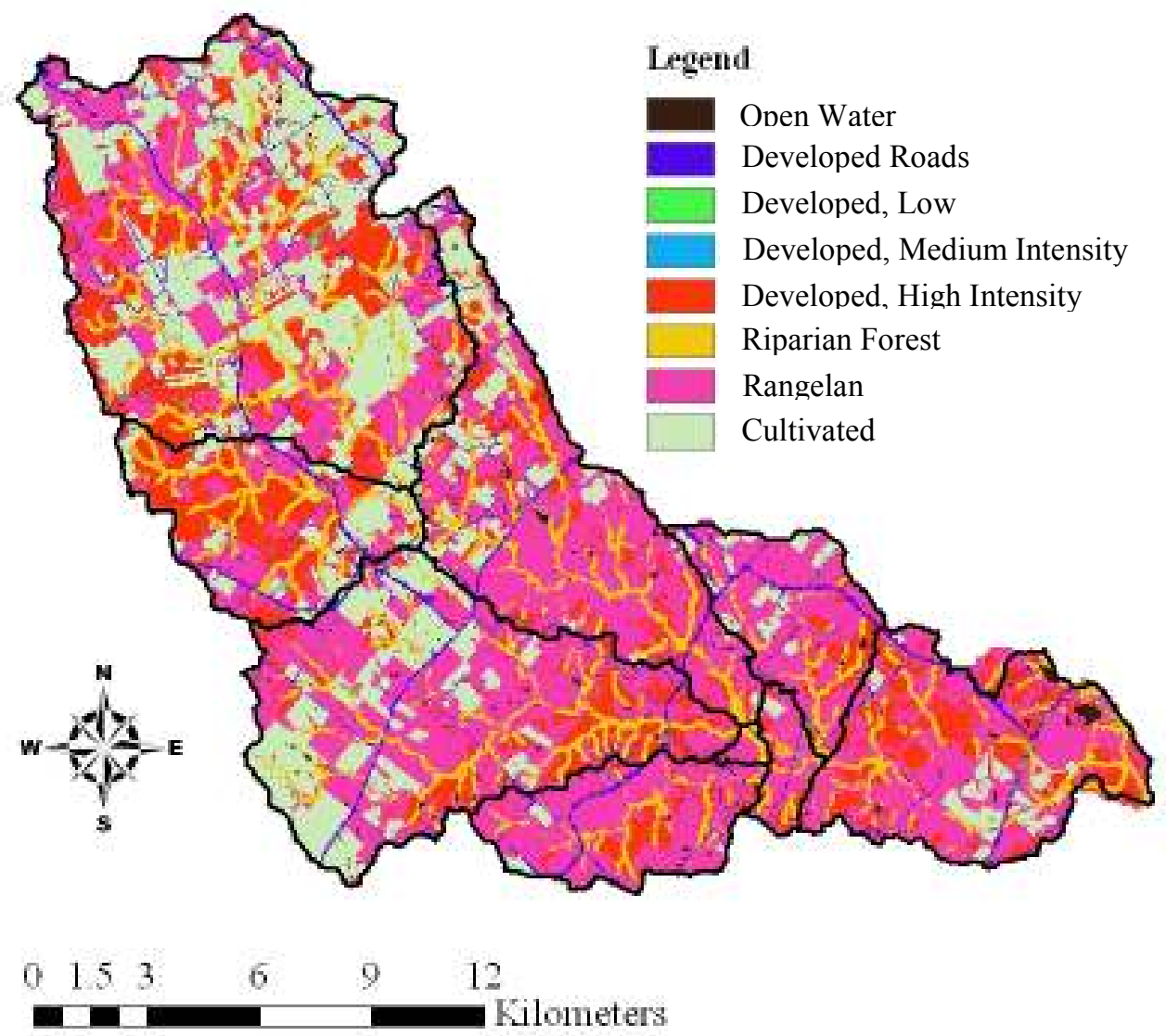

Figure 3.1. Representation of land use in the Cedar Creek watershed, Brazos County, Texas (U.S. Environmental Protection Agency 2010). 
Cameras were placed at observed wildlife trails or openings suitable for camera placement near each pre-determined grid point (Jeganathan et al. 2002, Claridge et al. 2004, Roberts et al. 2005, Trolle and Kéry 2005). Each camera (1 gigabyte flash card) was capable of storing approximately 1,000 still images and short video clips $(10 \mathrm{sec})$. I used apple and persimmon-scented gel on nearby substrate (e.g., thick branches, stumps) every 5 days as attractant. I determined density using mark-resight methods (Karanth and Nichols 1998, Jacobson et al. 1997, Main and Richardson 2002, Watts et al. 2008). Second, I determined meso-mammal density by analyzing trapping numbers in live-trap grids (Main and Richardson 2002). I trapped on both properties using a grid-design (42 traps total for each property; raccoon/feral cat, $81 \mathrm{~cm}$ x $25 \mathrm{~cm}$ x $30 \mathrm{~cm}$; Tomahawk Live Trap, Tomahawk, Wisconsin, USA) with 250-m spacing between traps that have been shown to adequately sample animals that were highly attracted to aromatic baits (e.g., raccoons, Virginia opossums). Trapping locations were randomly selected and trapped for 12 consecutive days using Tomahawk box traps baited with canned dog food, apples, bananas, and fish scent. I estimated density using mark-recapture methodologies (Krebs 1999). I uniquely marked captured animals using non-toxic hair dye and released them 5-7 minutes later (Appendix A). I immobilized animals using a Tomahawk squeeze cage to obviate the need for sedatives or tranquilizers. Sex, age, species, and unique natural marks were recorded. All information was recorded in database and within a Geographical Information System (GIS).

Additionally, I attempted to trap nine-banded armadillos (Dasypus novemcinctus) and eastern cottontails (Sylvilagus floridanus), and striped skunks (Mephitis mephitis) on 
both properties using trap arrays because each species was less attracted or seasonally attracted to baits. I fabricated the arrays from $61-\mathrm{cm}$ tall chicken fencing with $61-\mathrm{cm}$ long wooden stakes. Each array had 8-12 double-door raccoon/rabbit traps (43 traps total for each property; $48 \mathrm{~cm}$ x $15 \mathrm{~cm}$ x $15 \mathrm{~cm}$; Tomahawk Live Trap, Tomahawk, Wisconsin, USA) with variable array setups designed to take advantage of the local vegetative community and topography. Previous studies have successfully conducted research on meso-mammals using this technique (Faulhaber 2003).

\section{Escherichia coli Data}

I collected fecal material of major contributing species during mammal livetrapping (McCleery et al. 2005). Upon animal release, I collected all fecal material from the traps. I cleaned the trap thoroughly using bleach water and scrub brush and moved the trap (5-m radius) to prevent possible cross contamination of subsequent fecal samples (Rutala and Weber 2008). Fresh samples were sent to the laboratory at Texas A\&M University for analysis of $E$. coli concentration. Fresh samples directly from the source animal helped to reduce the risk of environmental contamination of the fecal samples. I collected fecal samples of relevant and dominant identified sources during the summer (2008 and 2009) and winter (2008) seasons.

I trapped and euthanized hogs during summer 2008 (9 traps) and summer 2009 (6 traps) for 7 days and 6 days respectively using 3 panel corral-style traps on property A (not allowed on Property B). Traps were baited daily with soured corn (max of 7.81 and locked open for 7 days prior to trapping to increase the potential success rate. I checked the traps daily and rebaited with corn as necessary during trapping. Hogs were 
euthanized with a single shot to the head and fecal samples were collected from euthanized hogs. I supplemented sampling on Property A by accompanying hog hunters in watersheds near the Brazos River (April 2009).

I captured white-tailed deer using drop nets (Lopez et al. 1998) on Property A. Drop nets were pre-baited for 7-10 days prior to capture with apple-scented corn. All deer were restrained with rope (legs bound) and a hood was placed over each animal's head. Average handling time was 5-10 minutes (no drugs used). I recorded sex, age and capture location (Lopez et al. 2003). Each animal received an ear tattoo as a permanent marker (Silvy 1975).

Texas A\&M University collaborators quantified E. coli numbers from characterized waste streams for all dominant identified sources using appropriate methods (TSSWCB Project Number 07-06, unpublished report). All collection and handling of fecal specimens was performed using protective gear (i.e., latex or nitrile gloves). All feces collected were placed in sterile Whirl-Pak containers (Nasco, Fort Atkinson, Wisconsin, USA). Fecal specimens were placed in an insulated cooler on ice during transport to the Biological and Agricultural Engineering laboratory atTexas A\&M University. Padia (2010) described the process used to analyze the fecal samples.

Fecal samples were analyzed and enumerated for E. coli using Colilert-18 method. All the samples were analyzed between 24 and $72 \mathrm{~h}$ after they were brought to the laboratory. A standard membrane-filtration method (EPA Method 1603) to enumerate E. coli in water was used to estimate $E$. coli concentrations. A direct count of $E$. coli was obtained based on the development of colonies that grew on the surface of the membrane filter placed on a selective nutrient medium. Only the plates having colonies between 30 and 300 were used to report $E$. coli concentrations as colony forming units (CFUs) per g of wet fecal material 


\section{Species-Specific Deposition and Spatial Analysis}

I conducted a comprehensive literature review to determine fecal shedding rate for relevant species. I then extrapolated floodplain-scale estimates of the amount of species-specific fecal material by combining these estimates with density estimates that I calculated (Morrison et al. 2001). Finally, I combined these data with E. coli concentrations found in fecal material collected from captured wildlife to find the species-specific amount of $E$. coli deposited into the watershed.

Proximity of fecal deposition to water body is directly correlated with the probability that it will infiltrate the stream system (Collins and Rutherford 2003). I determined spatial deposition behavior by using a random design to place $70-80$ individual $600 \mathrm{~m}^{2}$ transects within each study property (375 transects total). All fecal material found within these transects (Property A: summer 2008, winter 2008, summer 2009; Property B: summer 2008, winter 2009) was identified to species and located via handheld global positioning system (GPS).

\section{Data Analyses}

I used several methodologies to determine population densities and compared the results. I conducted Schnabel population density tests on all subject species. The Schnabel estimator is conservative and was the primary estimator for all species densities. I converted capture-recapture data for meso-mammals and white-tailed deer into encounter histories and used Program MARK (White and Burnham 1999) to develop abundance models. I used an information-theoretic approach (Burnham and Anderson 1998) to evaluate the null, behavioral, temporal, and requisite interaction 
models. I calculated model-averaged $95 \%$ confidence intervals for all plausible models ( $\leq 4$ AICc, Burnham et al. 1987). I compared these abundance estimates to estimates reported in the literature and to the Schnabel estimates to ensure validity (Lopez et al. 2003). Finally, in order to compare estimates against conservative numbers, I generated minimum densities for all species based on minimum number known alive from capture histories.

\section{RESULTS}

\section{Species Density}

I gathered white-tailed deer data (1,025 total pictures) concurrently with feral hogs (1,487 total pictures). I found insufficient numbers of naturally-marked hogs during any season to conduct model selection approaches. However, I could estimate effective sample area thus allowing conservative density estimation. I relied on Schnabel estimators and minimum number known alive to calculate conservative population densities for all species (Table 3.1). Schnabel estimates were comparable to model-selection techniques. I grid-trapped 2,328 traps-nights during the study (20082009). Additional array trapping totaled approximately 1,680 trap-nights I captured negligible numbers of rabbits, armadillos, and skunks using arrays. I had insufficient data to calculate feral hog Schnabel estimates for winter-spring 2008-2009 and summer 2009 and Virginia opossum estimates for summer 2008. I found that Property A had higher densities of raccoons, but Virginia opossums were approximately equal (Table 3.1) on each property. 


\section{Escherichia coli Data}

During the study, I collected 338 fecal samples from 182 individuals including: raccoon (Property A: $n=115$ samples; Property B: $n=62$ samples), Virginia opossum

(Property A: $n=43$ samples; Property B: $n=45$ samples), white-tailed deer (Property A: $n=6$ samples; other properties: $n=4$ samples), feral hog (Property A: $n=39$ samples; other properties: $n=6$ samples), nine-banded armadillo (Property A: $n=3$; Property B, $n=4$ ), and striped skunk (Property A, $n=6$; Property B, $n=5$ ).

\section{Species-Specific Deposition and Spatial Analysis}

According to the literature, feral hogs have the highest mean individual daily defecation rate of any of the study species (feral hogs: 1,121 g/day [Ohio State University Extension 2006, Mapston 2007], white-tailed deer: 500-772 g/day [McCullough 1982, Sawyer et al. 1990, Wittman Hydro Planning Associates, Inc. 2004], raccoon: 180-450 g/day [Sorvillo et al. 2002, Wittman Hydro Planning Associates, Inc. 2004], Virginia opossum: 75-108 g/day [Hopkins and Forbes 1979, Atwill et al. 2003]). I combined the highest and lowest seasonal density estimates with conservative estimates of fecal deposition rates and found that white-tailed deer, raccoons, and feral hogs deposited the most fecal material into the watershed. Although raccoon maximum deposition was much higher than white-tailed deer or feral hogs, the deposition estimates overlap extensively. Virginia opossums contributed the least fecal material of the sampled animals (Fig. 3.3). Using the fecal samples, I found that raccoons and Virginia opossums had the highest mean CFU/gram of fecal material of sampled species (Table 
3.2). Overall, I estimated that raccoons potentially deposited the most E. coli per $\mathrm{km}^{2}$, followed by feral hogs, Virginia opossums, and white-tailed deer (Table 3.3).

I collected 147 fecal samples during transects. Fecal samples were grouped by species, but across seasons and properties due to low sample sizes. White-tailed deer deposited fecal material closest to Cedar Creek $(n=77 ; \bar{x}=264.1 \mathrm{~m}, S D=204.1 \mathrm{~m})$ though the wide standard deviation demonstrates that I found white-tailed deer fecal material throughout the floodplain. Feral hogs were the next closest $(n=25 ; \bar{x}=279.4$ $\mathrm{m}, S D=106.1 \mathrm{~m})$, followed by raccoons $(n=18 ; \bar{x}=335.1 \mathrm{~m}, S D=235.1 \mathrm{~m})$.

The spatial data I collected was largely inconclusive. Despite differences in range sizes, I found that fecal deposition by each species was spread throughout the floodplain. White-tailed deer were technically closer, though feral hogs and raccoons were not much further on average. Raccoon fecal material was widespread throughout the floodplain. Additionally, raccoons are documented occasionally defecating directly into water bodies (Lotze and Anderson 1979). These defecations are not discoverable, thereby biasing the results. The interesting component was that white-tailed deer were 
Table 3.1. Compilation of density estimates for Property A and Property B, Brazos County, Texas 2008-2009.

\begin{tabular}{|c|c|c|c|c|c|c|}
\hline Property & Species & Season & $\begin{array}{c}\text { Density } \\
\left(\mathrm{km}^{2}\right)\end{array}$ & $\begin{array}{l}\text { CI- } \\
\text { Low }\end{array}$ & $\begin{array}{l}\text { CI- } \\
\text { High }\end{array}$ & $\begin{array}{c}\text { Minimum } \\
\text { density } \\
\left(\mathrm{km}^{2}\right)^{\mathrm{a}}\end{array}$ \\
\hline \multirow[t]{11}{*}{ A } & \multirow[t]{3}{*}{ Raccoon } & Summer 2008 & 87.63 & 73.87 & 107.71 & 48.92 \\
\hline & & Winter 2008 & 58.87 & 46.09 & 81.46 & 31.45 \\
\hline & & Summer 2009 & 37.97 & 32.85 & 44.98 & 32.57 \\
\hline & $\begin{array}{l}\text { Virginia } \\
\text { Opossum }\end{array}$ & Summer 2008 & 11.98 & 10.02 & 14.909 & 11.74 \\
\hline & \multirow{3}{*}{$\begin{array}{l}\text { White- } \\
\text { tailed Deer }\end{array}$} & Summer 2008 & 16.04 & 14.34 & 18.20 & 15.72 \\
\hline & & Winter 2008 & 20.56 & 15.99 & 28.91 & 13.88 \\
\hline & & $\begin{array}{l}\text { Summer } \\
2009^{a}\end{array}$ & - & - & - & 21.15 \\
\hline & \multirow[t]{4}{*}{ Feral Hog } & $\begin{array}{l}\text { Summer } \\
2008^{\mathrm{a}}\end{array}$ & - & - & - & 7.52 \\
\hline & & Fall $2008^{a}$ & - & - & - & 5.09 \\
\hline & & $\begin{array}{l}\text { Win-Spr } \\
2008 / 2009^{a}\end{array}$ & - & - & - & 4.64 \\
\hline & & $\begin{array}{l}\text { Summer } \\
2009^{\mathrm{a}}\end{array}$ & - & - & - & 3.32 \\
\hline \multirow[t]{4}{*}{ B } & \multirow[t]{2}{*}{ Raccoon } & Summer 2008 & 57.87 & 47.28 & 74.53 & 33.02 \\
\hline & & Winter 2008 & 34.30 & 29.21 & 41.53 & 26.84 \\
\hline & \multirow{2}{*}{$\begin{array}{l}\text { Virginia } \\
\text { Opossum }\end{array}$} & Summer 2008 & 10.78 & 8.99 & 13.49 & 10.95 \\
\hline & & Winter 2008 & 4.33 & 3.08 & 7.32 & 3.94 \\
\hline
\end{tabular}

${ }^{\mathrm{a}}$ Derived from minimum number known alive 


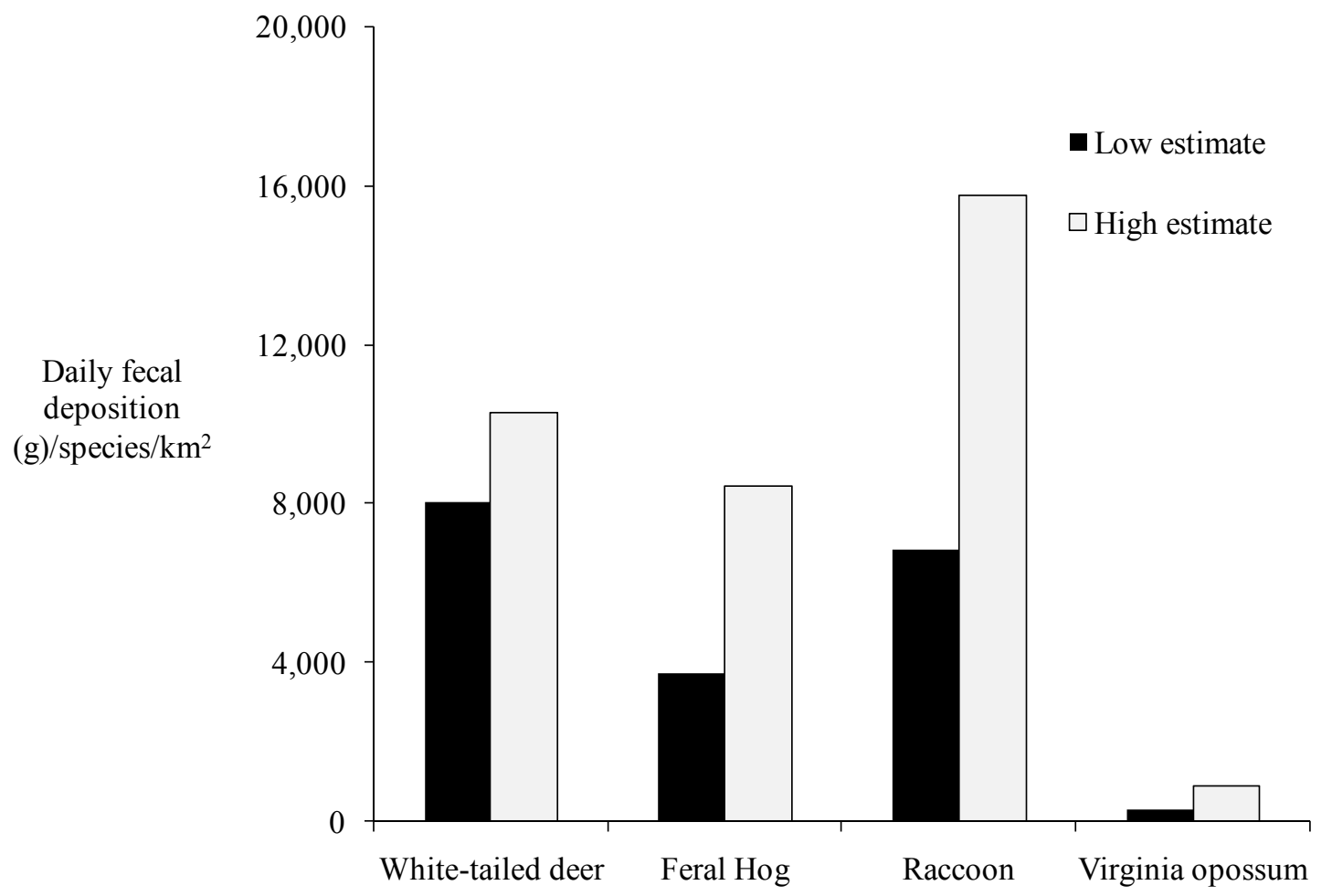

Figure 3.2. Summary of estimated daily fecal deposit by species per $\mathrm{km}^{2}$, Cedar Creek, Brazos County, Texas, 2008-2009. 
Table 3.2. Summary of $E$. coli concentrations in fecal material sampled from wildlife species, Brazos County, Texas, 2008-2009.

\begin{tabular}{|c|c|c|c|}
\hline Species & $\bar{x}(\mathrm{CFU} / \mathrm{g})$ & Range-low & Range-high \\
\hline White-tailed deer & $2.89 \times 10^{5}$ & $4.00 \times 10^{3}$ & $5.20 \times 10^{5}$ \\
\hline Feral hog & $5.63 \times 10^{6}$ & $9.80 \times 10^{4}$ & $4.17 \times 10^{7}$ \\
\hline Raccoon & $1.59 \times 10^{7}$ & $1.88 \times 10^{5}$ & $3.16 \times 10^{9}$ \\
\hline Virginia opossum & $1.60 \times 10^{7}$ & $1.82 \times 10^{4}$ & $2.78 \times 10^{9}$ \\
\hline
\end{tabular}


Table 3.3. Estimated daily E. coli deposition by each study wildlife species, Brazos County, USA, 2009-2009 (conservative defecation rate x mean E. coli concentration $\mathrm{x}$ species density).

\begin{tabular}{|c|c|c|c|c|c|}
\hline Property & Species & Season & $\bar{x}\left(\mathrm{CFU} / \mathrm{km}^{2}\right)$ & CI-low & CI-high \\
\hline \multirow[t]{11}{*}{ A } & \multirow[t]{3}{*}{ Raccoon } & Summer 2008 & $2.51 \times 10^{11}$ & $2.11 \times 10^{11}$ & $3.08 \times 10^{11}$ \\
\hline & & Winter 2008 & $1.69 \times 10^{11}$ & $1.32 \times 10^{11}$ & $2.33 \times 10^{11}$ \\
\hline & & Summer 2009 & $1.08 \times 10^{11}$ & $9.40 \times 10^{10}$ & $1.29 \times 10^{11}$ \\
\hline & $\begin{array}{l}\text { Virginia } \\
\text { Opossum }\end{array}$ & Summer 2008 & $1.44 \times 10^{10}$ & $1.20 \times 10^{10}$ & $1.79 \times 10^{10}$ \\
\hline & \multirow{3}{*}{$\begin{array}{l}\text { White- } \\
\text { tailed Deer }\end{array}$} & Summer 2008 & $2.32 \times 10^{9}$ & $2.07 \times 10^{9}$ & $2.63 \times 10^{9}$ \\
\hline & & Winter 2008 & $2.97 \times 10^{9}$ & $2.31 \times 10^{9}$ & $4.18 \times 10^{9}$ \\
\hline & & Summer 2009 & $3.06 \times 10^{9 \mathrm{a}}$ & - & - \\
\hline & \multirow[t]{4}{*}{ Feral Hog } & Summer 2008 & $4.75 \times 10^{10 \mathrm{a}}$ & - & - \\
\hline & & Fall 2008 & $3.21 \times 10^{10 \mathrm{a}}$ & - & - \\
\hline & & $\begin{array}{l}\text { Win.-Spr. } \\
\text { 2008/2009 }\end{array}$ & $2.93 \times 10^{10 a}$ & - & - \\
\hline & & Summer 2009 & $2.10 \times 10^{10 \mathrm{a}}$ & - & - \\
\hline \multirow[t]{4}{*}{ B } & \multirow[t]{2}{*}{ Raccoon } & Summer 2008 & $1.66 \times 10^{11}$ & $1.35 \times 10^{11}$ & $2.13 \times 10^{11}$ \\
\hline & & Winter 2008 & $9.82 \times 10^{10}$ & $8.36 \times 10^{10}$ & $1.19 \times 10^{11}$ \\
\hline & \multirow{2}{*}{$\begin{array}{l}\text { Virginia } \\
\text { Opossum }\end{array}$} & Summer 2008 & $1.29 \times 10^{10}$ & $1.08 \times 10^{10}$ & $1.62 \times 10^{10}$ \\
\hline & & Winter 2008 & $5.20 \times 10^{9}$ & $3.70 \times 10^{9}$ & $8.78 \times 10^{9}$ \\
\hline
\end{tabular}

${ }^{\mathrm{a}}$ Estimates derived from minimum number known alive 
the dominant species represented in transects $(52.4 \%)$ followed by feral hogs $(17.0 \%)$, raccoons $(12.2 \%)$, and other $(15.7 \%)$. I could not accurately determine the age of the fecal material, making attempts at standardizing mass measurements impossible. These data indicate that white-tailed deer and feral hogs were significant contributors of fecal material to the Cedar Creek floodplain.

\section{DISCUSSION}

I found that estimated density of observed species was within reasonable boundaries established by other research (white-tailed deer: Michael 1965; hogs: Sweitzer et al. 2000; Virginia opossums: Gehrt et al. 1997; raccoons: Riley et al. 1998, Blackwell et al. 2004). Although, observed raccoon density was higher than many studies, it fell within population density estimates for suburban areas and suburban-rural interfaces (Riley et al. 1998). My study area was largely a rural ranching area with interspersed infrequent houses. However, the area was intensively, though variably, managed for ranching interests (e.g., rotational grazing, fertilizer application, food provisions) and also subdivided in other areas of the watershed for smaller properties (2.0-10.1 ha parcels). Declines in raccoon populations were observed on both properties over the course of the study. Seasonal variation was expected; however, highly divergent rain patterns from Summer 2008 (dry) to Summer 2009 (wet) likely impacted populations and population estimates. Feral hog estimates were certainly impacted by concomitant lethal hog sampling efforts. Minimum number known alive estimates of the feral hog population reflected a generally declining population over the course of the study. The population estimates also may have been a product of differing rain patterns 
that allowed hogs to move further away from the bottomlands on the study property. I expect that the feral hog population was higher than the results indicated, but research into hog populations in similar habitats indicates that the numbers are likely fairly accurate. Property A generally had higher densities of raccoons and Virginia opossums than property B. This may be partially due to less intensive grazing and lack of exotic grazers on the property. Vegetational differences due to grazing intensity were evident (e.g., grass species present, height of grazed vegetation). As an obvious example, traps located in the center of pastures captured far fewer meso-mammals than those located near the periphery.

Many water quality researchers rely on existing data to determine wildlife densities and per capita pollution impacts when creating models or designing management strategies. Although most wildlife data in water quality studies originated from state natural resource agencies, the methodology used to attain density estimates varied significantly. For instance, Parajuli et al. (2008) evaluated the effects of best management practices on water quality and relied on summer roadkill indices and expert opinions to determine wildlife densities. Kaller et al. (2007) compared water quality in watersheds to determine the impact of feral hogs. They relied on harvest data to determine population trends. In their model of microbial contaminants from grazed fields, Tian et al. (2002) used stock units that covered expected wildlife contribution without getting wildlife data. In a TMDL developed in Virginia, Culver et al. (2002) found that white-tailed deer contributed by far the most fecal coliform to the system, followed by raccoons, and geese. Brannan et al. (2001) found that white-tailed deer 
contributed the most fecal coliform to the system followed distantly by wood ducks, mallards, and geese. Despite having the third highest population, raccoons contributed only the fifth highest amount of fecal. White-tailed deer contributed the least of all 4 species sampled; while raccoons and feral hogs were the largest potential contributors. Minimal differences in fecal deposition distance from Cedar Creek indicated that the potential E. coli contribution results accurately reflect the important contributing species. However, I could not detect fecal contributions directly into Cedar Creek, thus potentially increasing bias. Direct contribution of fecal material by wildlife into water bodies cannot be ruled out and has been documented in raccoons (Lotze and Anderson 1979).

\section{CONCLUSION}

Free-ranging mammals in my study area were significant contributors of E. coli into floodplains. Raccoons are larger potential contributors than mammals like feral hogs and white-tailed deer. This is exacerbated by the fact that raccoons stay near water and are known to defecate in water sources (Lotze and Anderson 1979, spatial data). Feral hogs largely remain near water sources (Mapston 2007); however, the abundance of water on the properties (water tanks) probably allowed unrestricted movement away from bottomland streams. Feral hogs are known for a high degree of coprophagy likely further reducing their fecal contribution. White-tailed deer defecated frequently and in relatively large amounts; however, they had relatively low E. coli concentration in their fecal material. 
Little can be done to practically manage meso-mammal populations, nor would such management for water quality improvement necessarily be advisable. Reduction of meso-mammal populations would likely have additional unintended collateral consequences (e.g., trophic cascades, prey population increases, [Naiman 1988]). White-tailed deer are arguably the most important game species in Texas, but little population management could practically be directed towards reducing their impact on water quality. Hogs are potential candidates for mammal management due to their acknowledged nature as an invasive exotic with a plethora of documented ecological damage. Reduction of hogs may not have a large impact on water quality, but this research adds to the already compelling evidence supporting feral hog control efforts.

Few studies have attempted to determine the important contributing species in the watershed, provide density estimates of those species, and comprehensively collect fecal samples from them. I attempted to find all of these data for a specific water body so that the methodology could be tested and the results applied to other similar areas. Finally, I have shown in detail that wildlife have an important impact on E. coli deposition, thus adding uncertainty to water quality models that have relied on less precise or unproven data. Further research must be undertaken to determine fecal degradation rates and E. coli viability in different fecal morphologies. Additionally, it was impractical for me to conduct experiments to estimate fecal deposition rates due to time, manpower, and financial constraints. Projects in the future should budget these necessities in order to increase the precision and usefulness of the research. 


\section{CHAPTER IV}

\section{A MODEL OF FREE-RANGING WILDLIFE CONTRIBUTION OF ESCHERICHIA}

\section{COLI}

\section{SYNOPSIS}

Free-ranging wildlife are considered important contributors to fecal pollution in United States water bodies. Non-pathogenic Escherichia coli (E. coli) is a bacteria located in warm-blooded animals and is therefore used by agencies and researchers as a so-called indicator organism to determine the amount of fecal material present in a water body. I constructed a model that incorporated spatial data, population density estimates, defecation rates, $E$. coli loads in feces estimates, and $E$. coli survival for the three most important contributing wildlife of fecal pollution as determined in previous chapters: raccoons (Procyon lotor), white-tailed deer (Odocoileus virginianus), and feral hogs (Sus scrofa),1. I conducted sensitivity analyses to determine the most important variables and to analyze outcomes of prospective management strategies. I found that E. coli survival was the most important parameters in determining the amount of E. coli in the floodplain, followed by defecation rates and population densities. Although this research indicates that $E$. coli survival should be the primary focus for future research, all of the tested parameters are either location specific (i.e., population density) or have extremely scarce data (i.e., defecation rate, E. coli survival). For wildlife management actions, adjustment of raccoon population density was the most impactful on E. coli load in the floodplain. Although white-tailed deer and feral hogs were found much less important, managers must be cautioned that spatial selection for fecal deposition is 
location specific and could significantly impact which species are considered the most important contributors. Lastly, habitat quality proved an important management consideration; thus emphasizing that management of wildlife and water quality should always include habitat management.

\section{INTRODUCTION}

Fecal pollution into water bodies continues in the United States despite concerted efforts to limit sources. Much of the focus has understandably landed on point-source polluters. As obvious single sources, these are easier to identify, regulate, and reduce. Certainly, researchers and regulators have understood, though, that non-point source pollution, originating across floodplains and watersheds, presents an important and onerous problem. As complex and inter-related sources of pollution combine, the burden of identifying and mitigating the important contributors increases in difficulty and cost. Understanding of fecal sources is an important initial step in any mitigation efforts (Streets and Holden 2003). Increasingly, free-ranging wildlife are seen as important fecal pollution contributors alongside humans and domesticated animals (Fischer et al. 2001, Lamendella et al. 2006). However, there is a comparative dearth of comprehensive research on the subject (Chapter II).

I created a structured model of wildlife Escherichia coli (E. coli) contribution into a Texas floodplain that built upon basic research documented in this dissertation (Chapters II-III). Structured models allow stochasticity in important variables and are thus easily manipulated and analyzed (Lopez 2001). Additionally models, as simple representations of systems, are desired when field or laboratory experimentation on 
those systems is untenable due to scope or cost (Turner et al. 1995). Models, however, are processing engines that produce results sensitive to the quality of source data, thus necessitating rigor in data inclusion.

I used this structured model to complete the following study objectives. First, conduct a sensitivity analysis to determine the impact of individual parameters and thus, direct areas of future research. Second, provide natural resource managers with reliable data illuminating important contributors of fecal pollution and the likely outcomes of various management strategies. Together, these objectives help designate areas of research need, while providing management advice.

\section{METHODS}

\section{Study Area}

Cedar Creek is located in southeast Texas in the Post Oak Savannah ecoregion. Cedar Creek flows southeast for a total of approximately $44 \mathrm{~km}$ through Robertson County and the northern part of Brazos County before emptying into the Navasota River on the eastern border of Brazos County. Density data, spatial data, and E. coli concentration data were all collected in the Cedar Creek watershed (Chapter III).

\section{Model Overview}

I used the modeling program STELLA (ISEE Systems, Hanover, New Hampshire, USA) to create a structured model based on daily E. coli deposition rates extrapolated into a likely ambient $E$. coli load originating from free-ranging wildlife (Fig. 4.1). Species determined as important E. coli contributors were modeled as discrete entities with individually adjustable parameters. The model allowed seasonal 


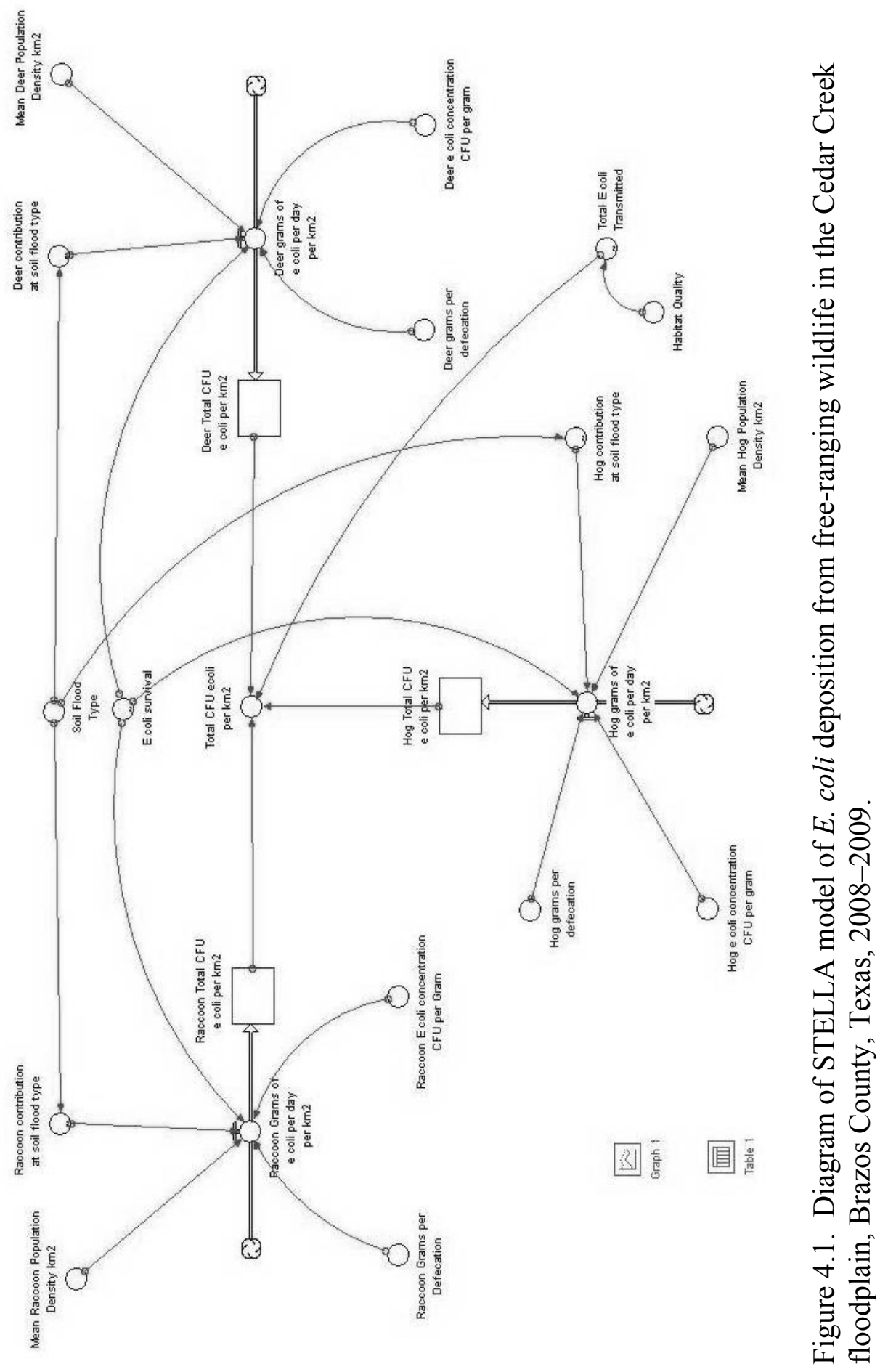


adjustments to super variables such as $E$. coli survival and flood extent. I determined spatial selection for important species and floodplain scale using ArcGIS 9.3.1 (Environmental Systems Research Institute (ESRI), Redlands, California, USA) with the Soil Data Viewer extension (Natural Resources Conservation Service [NRCS] 2010). I conducted a sensitivity analysis of model parameters important to E. coli load (i.e., E. coli survival, wildlife densities, and fecal deposition rates). I also conducted a sensitivity analysis of individual management plans (increase or reduction of individual wildlife species) to determine potential impacts.

\section{Data Collection}

I gathered the source data from multiple sources. I determined population densities of important species in Chapter III. I determined spatial selection in Chapter III. Species-specific E. coli concentration in fecal material was determined in Chapter III. I conducted a meta-analysis of water quality research to determine fecal deposition rates in Chapter II. I obtained property ownership, land use, and county streams shapefiles from Brazos County Engineer's office and soil inundation shapefiles and the Soil Data Viewer from the NRCS.

\section{Wildlife Density}

Seasonal variations in population density were integrated into subsequent analyses. Age and sex variations were not determinable in these density estimations. Density was integrated as a normal distribution with mean and standard deviation derived from the data. 


\section{Spatial Fecal Deposition}

The NRCS provided shapefiles differentiating various soil types based on probability of overland water flow during flooding or rainfall events. I assumed percentage of fecal material from each species in each soil class represented an area selection.

\section{Habitat Quality, E. coli Transmission, and Fecal Deposition Rates}

In the Cedar Creek floodplain, habitat quality for species studied is largely tied to cattle grazing management. I assumed that overgrazing decreased surface vegetation. Increased surface vegetation can slow overland flow and decrease erosion (Loch 2000, Wainwright et al. 2000). I assumed that overland flow was impacted by habitat quality. As habitat quality increased, surface vegetation increased, and E. coli transmission from the floodplain into Cedar Creek directly decreased. I used a scale of $0.0-1.0$ as the basis for habitat quality, with 1.0 being the best habitat quality. I divided habitat quality into high (0.7-1.0), medium $(0.4-0.69$, and low $(0.0-0.39)$ values that varied randomly and were multiplied with total $E$. coli deposition to estimate $E$. coli transmission into the water body at different habitat qualities. I incorporated fecal deposition rates as a species-specific random variable bounded by the ranges discovered in the literature.

\section{E. coli Survival and Concentration}

I found no research that specifically addressed survival for E. coli in fecal material for species in this research (Renter et al. 2001). I therefore, assumed reduced survival of $E$. coli compared to existing research in cattle feces and sediments (Bach et al. 2005, Meays et al. 2005, Scott et al. 2006). I maintained survival curves similar to 
existing research (indirectly proportional), but shortened the timeframe (mean of approximately 14 days) to account for smaller fecal morphology. In the absence of

detailed data, I assumed equal E. coli survival for different species' fecal morphology, though I differentiated survival based on season (50\% increase in survival time for winter compared to summer). Variance estimates were derived using random numbers bounded by the range estimates (Padia 2010).

\section{Model Use}

I analyzed the contribution of raccoons, feral hogs, and white-tailed deer by running a set of 1,000 simulations for each variable stage. In order to both determine important variables for further research I conducted the following. First, I determined a medium value for each critical parameter (i.e., mean population density for each species, median defecation rate for each species, and a mean $E$. coli survival rate). I then varied each parameter individually (medium, high $[+50 \%]$, and low $[-50 \%]$ ) while keeping the other parameters at their medium setting (Table 4.1). I ran 1,000 simulations for each adjustment. I then subtracted mean E. coli loads found for the minimum parameter value from the maximum parameter value to determine the range of change. This provided an estimate of the impact changing the parameter had on overall E. coli load. I then determined impacts of various management strategies by adjusting individual species densities $(-50 \%,-75 \%,+50 \%,+75 \%)$ and $E$. coli transmission while keeping other parameters at medium settings. This provided baseline expected E. coli loads and 
Table 4.1. Low, medium, and high parameter estimates used in E. coli deposition analysis on Cedar Creek, Brazos County, Texas, 2008-2009.

\begin{tabular}{|c|c|c|c|}
\hline Parameter & Low & Medium & High \\
\hline \multirow{4}{*}{$\begin{array}{l}\text { Population } \\
\text { Density } \\
\left(\mathrm{km}^{2}\right)\end{array}$} & Species $=$ mean $(S D)$ & Species $=$ mean $(S D)$ & Species $=$ mean $(S D)$ \\
\hline & $\begin{array}{l}\text { Raccoon }= \\
25.82(9.3)\end{array}$ & $\begin{array}{c}\text { Raccoon }= \\
51.64(24.84)\end{array}$ & $\begin{array}{c}\text { Raccoon }= \\
77.46(31.70)\end{array}$ \\
\hline & Deer $=9.41(0.03)$ & Deer $=18.83(0.04)$ & Deer $=28.25(0.05)$ \\
\hline & $\operatorname{Hog}=2.51(0.13)$ & $\operatorname{Hog}=5.02(0.18)$ & $\operatorname{Hog}=7.52(0.23)$ \\
\hline \multirow[t]{3}{*}{$\begin{array}{l}\text { E. coli } \\
\text { Survival } \\
\text { (days) }\end{array}$} & 7 & 14 & 21 \\
\hline & Species $=$ range & Species $=$ range & Species $=$ range \\
\hline & Raccoon $=80-100$ & Raccoon $=170-190$ & Raccoon $=350-370$ \\
\hline \multirow{2}{*}{$\begin{array}{l}\text { Fecal } \\
\text { Deposition } \\
\text { Rate } \\
\text { (g/day) }\end{array}$} & Deer $=240-260$ & Deer $=490-510$ & Deer $=740-760$ \\
\hline & $\operatorname{Hog}=550-570$ & $\operatorname{Hog}=1,110-1,130$ & $\operatorname{Hog}=1,670-1,690$ \\
\hline $\begin{array}{l}\text { Habitat } \\
\text { Quality } \\
\text { Scale }\end{array}$ & $0.0-0.39$ & $0.4-0.69$ & $0.7-1.0$ \\
\hline
\end{tabular}


the expected E. coli loads stemming from alterations in species density. I also investigated the impact of various habitat management strategies by adjusting the habitat quality parameter (Table 4.1). I continued the management analysis methodology by subtracting the minimum values from the maximum values to determine overall impact on E. coli load.

\section{RESULTS}

I conducted sensitivity analyses to determine the important impactors on E. coli load in the floodplain and to illuminate important parameters for further study. I found that changes in E. coli survival had the largest impact on E. coli load in the floodplain (maximum value - minimum value $=2.26 \times 10^{15} \mathrm{CFU} / \mathrm{km}^{2}$; Fig. 4.2). This was

followed by population density (maximum value - minimum value $=2.1 \times 10^{15}$ $\mathrm{CFU} / \mathrm{km}^{2}$ ) and defecation rate (maximum value - minimum value $=2.05 \times 10^{15}$ $\left.\mathrm{CFU} / \mathrm{km}^{2}\right)$.

I found that despite increased $E$. coli survival (winter $=21$ days, summer $=14$ days) during the winter, summer E. coli loads were estimated to be higher during the summer (Property A: $\bar{x}=8.34 \times 10^{15}, S D=2.16 \times 10^{15}$; Property B: $\bar{x}=4.41 \times 10^{15}, S D$ $=8.81 \times 10^{14}$ ) compared to the winter (Property A: $\bar{x}=8.12 \times 10^{15} \mathrm{CFU} / \mathrm{km}^{2}, S D=1.79 \mathrm{x}$ $10^{15}$; Property B: $\bar{x}=4.20 \times 10^{15}, 5.80 \times 10^{14}$ ).

In order to determine potential impacts on E. coli load in the floodplain, I adjusted wildlife populations to mimic various management efforts for raccoons, whitetailed deer, and feral hogs. Due to relatively small impacts on E. coli load for whitetailed deer and feral hogs, stochastic effects resulted in non-proportional changes from 
population adjustments. Adjustment of raccoon density had, by a large margin, the greatest impact on E. coli load. White-tailed deer and feral hogs had similar impacts to each other when population densities were reduced (Table 4.2). I was unable to produce credible results from increases in feral hog densities. This was likely due to the relatively low percentage of hog fecal samples found in the floodplain $(12.5 \%)$ and small estimated population densities. Combined these would allow changes that were unrealistic (E. coli reduction resulting population increase) in the present format of the model.

I then investigated the impact of habitat management on E. coli load in the floodplain. I discovered that the impact of habitat quality was important to the overall $E$. coli load in the floodplain. The difference in overall E. coli loads between high parameter settings and low $\left(1.26 \times 10^{15} \mathrm{CFU} / \mathrm{km}^{2}\right)$ was high, elucidating the importance of habitat management under the model parameters. 


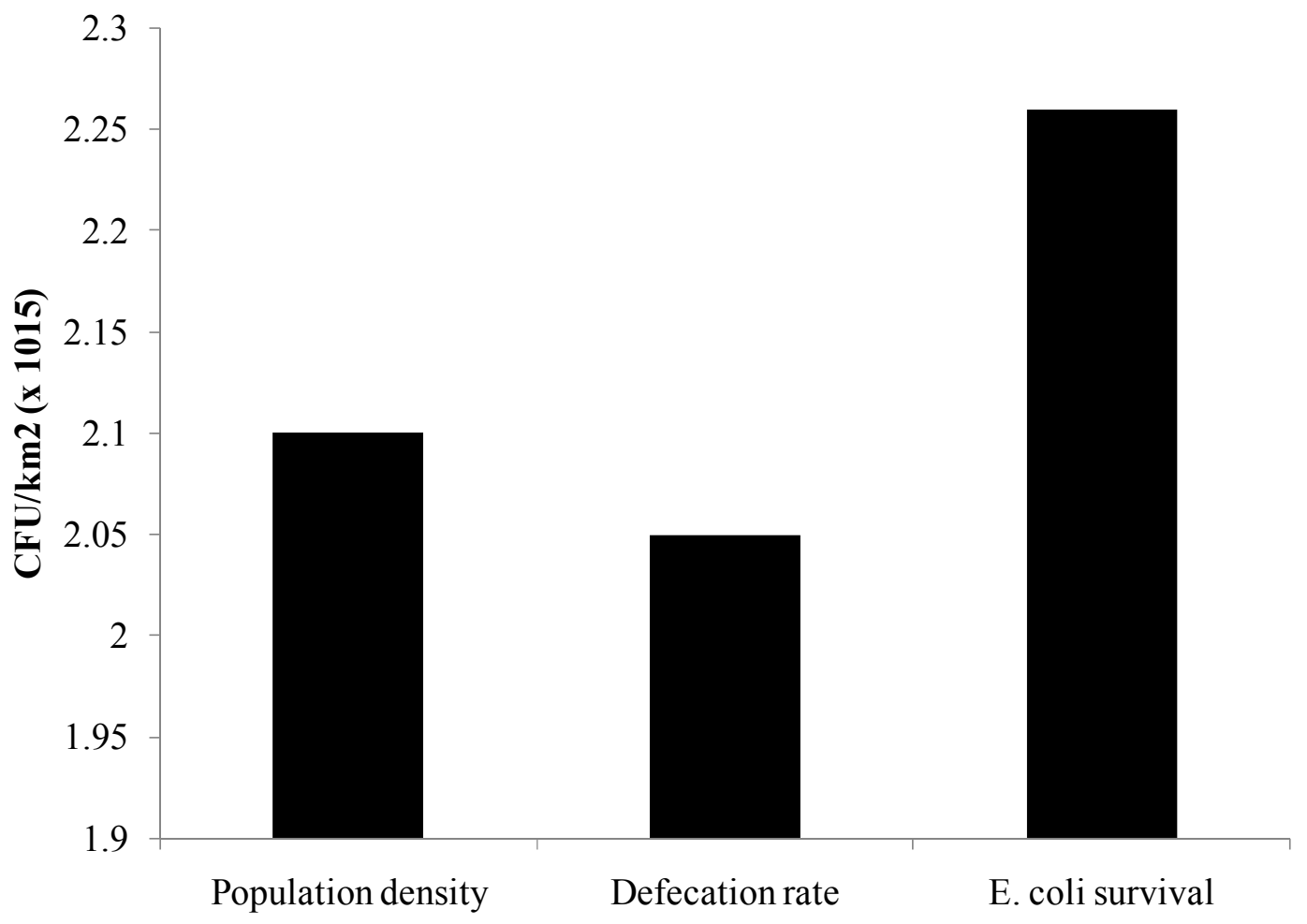

Figure 4.2. Estimate of the impact of each parameter on overall E. coli load (subtraction of the mean $E$. coli loads found for the minimum parameter value from the maximum parameter value to determine the range of change). 
Table 4.2. Changes in potential E. coli load based on population density adjustments in Cedar Creek, Brazos County, Texas, 2008-2009.

\begin{tabular}{|c|c|c|}
\hline Species & E. coli reduction $\left(\mathrm{CFU} / \mathrm{km}^{2}\right)$ & E. coli increase $\left(\mathrm{CFU} / \mathrm{km}^{2}\right)$ \\
\hline \multicolumn{3}{|l|}{ Raccoon } \\
\hline $50 \%$ & $3.82 \times 10^{15}$ & $3.72 \times 10^{15}$ \\
\hline $75 \%$ & $5.71 \times 10^{15}$ & $5.70 \times 10^{15}$ \\
\hline \multicolumn{3}{|l|}{ Deer } \\
\hline $50 \%$ & $6.62 \times 10^{13}$ & $5.33 \times 10^{13}$ \\
\hline $75 \%$ & $4.82 \times 10^{13}$ & $4.98 \times 10^{13}$ \\
\hline \multicolumn{3}{|l|}{ Hog } \\
\hline $50 \%$ & $3.62 \times 10^{13}$ & - \\
\hline $75 \%$ & $6.32 \times 10^{13}$ & - \\
\hline
\end{tabular}




\section{DISCUSSION}

Although a simple representation of the E. coli deposition system in Cedar Creek, this model is a usable structure based on proven data. This model can provide researchers and managers with results that incorporate parameter variability for more realistic simulations. The ultimate output of the model is potential E. coli density, which users can easily convert to total E. coli in the study area floodplain. Although, designed to operate simply, this model has several important issues that may impact results. First, species occurrence in the floodplain is location specific. I urge users to use spatial distribution data specific to the water body of interest. Second, E. coli survival and fecal deposition rates are remarkably little studied thus adding uncertainty to the overall model.

\section{Important Parameters}

I found that defecation rate was the most impactful parameter I tested during the sensitivity analyses. Population density and E. coli survival were important, but less than defecation rate. Due to the relatively large amount of $E$. coli in each gram of fecal material, even small changes in defecation rate could impact $E$. coli loads in the floodplain a great deal. This indicates that defecation rate is the parameter most in need of additional research. Due to the paucity of relevant defecation data for feral hogs and raccoons, I was forced to use data that may have had little application outside the target areas with few indications of variability or accuracy. Further study of defecation rates is critical to reducing uncertainty in this model and increasing understanding of wildlife contribution of E. coli in general. E. coli survival as it relates to fecal morphology and 
area of deposition also requires additional research. I chose conservative E. coli survival estimates (7 days, 14 days, 21 days); however, significantly different survival would change the estimated ambient $E$. coli in the system.

\section{Management Implications}

The wildlife manager has the option of adjusting the populations of select wildlife as necessary. This is contingent upon having accurate information about the population of each species. Under conditions recognized in the Cedar Creek watershed, raccoon density impacted the system far more than white-tailed deer or feral hogs. Managers are cautioned that under different spatial selection relationships (e.g., hogs are in the floodplain more often than I recorded), species density impact may differ. I surmise that increased hog presence in the floodplain is likely, and would make feral hog population reduction more impactful on potential E. coli loads. This is supported by other studies that document feral hogs remain in close proximity to water (Graves 1984, Mapston 2007). My findings have obvious implications for managers. Reduction of raccoon populations, although likely impactful on floodplain E. coli load, are only practical in areas of over population. Wide-scale reduction of native meso-mammal populations can have negative impacts on the local trophic system (Naiman 1988). Additionally, studies have demonstrated that raccoon reduction can lead to population increases in other meso-mammals (Kasparian et al. 2004). For instance, I found Virginia opossums had E. coli loads equal to raccoons (Chapter III); therefore, a potential population increase would cause concomitant increases in floodplain E. coli load. White-tailed deer population management is already a mature field; however, population 
reductions are generally avoided in well-managed systems. Population density is an important parameter that is nearly always a primary consideration in population management. Again, areas of white-tailed deer overpopulation may benefit from reduction. Feral hogs are the most likely candidate for population reduction. They are an invasive exotic species capable of widespread damage and documented disease transmission (Hone et al. 1992, Mapston 2007). Even at the relatively low documented occurrence in the Cedar Creek floodplain, population reduction would likely decrease $E$. coli loads. At greater hog densities, the benefits to population reduction would increase (Kaller et al. 2007).

I found that habitat quality was important to transmission of E. coli load. Both Property A and B remain working ranches with cattle herds. In the context of these properties, habitat management stems from grazing patterns that then impact habitat quality for meso-mammals, deer, and hogs. Improved vegetation cover would likely decrease E. coli transmission from the floodplain to the water body as deeper soils and increased vegetation cover increase water penetration and reduce overland flow (Loch 2000, Wainwright et al. 2000). This improvement could take the form of quality grazing management, brush management, and erosion control. Conversely, overgrazing and brush encroachment would likely increase transmission as bare relatively impermeable ground spreads.

\section{CONCLUSION}

Wildlife are important contributors of $E$. coli into floodplains. Unfortunately, existing data is scarce, fragmented, and difficult to access. Further research to offset 
these short-comings is critical in future evaluations of wildlife contributions to water pollution. Although, future research is important, management decisions must be made in the present. The overall worth of management of wildlife for water quality is only, arguably, determinable on a location basis and requires additional debate both scientifically and throughout society. 


\section{CHAPTER V}

\section{CONCLUSION AND IMPLICATIONS}

In this dissertation, I analyzed the role of wildlife in the deposition of Escherichia coli (E. coli) into a Texas floodplain. Each chapter was a component of my attempt to understand the heretofore little understood impact of wildlife on water quality. In my final chapter, I recount the important points of each chapter and synthesize recommendations.

In Chapter II, I found that water quality research relied heavily upon wildlife density estimates. Water quality researchers must obtain this data from outside sources such as state natural resource agencies; however, I found a paucity of relevant and reliable wildlife data used for water quality research. Although, much of the water research demonstrated that wildlife was an important contributor of fecal pollution, the quality of the data varied. I recommend that, when possible, water quality research include wildlife density estimates gathered in the study watersheds. I would recommend vigilance in using extant data. Wildlife professionals should validate this data and determine that it is biologically relevant to areas studied.

In Chapter III, I found that wildlife were important contributors of E. coli to Cedar Creek. Raccoons provided the most E. coli into the floodplain followed by whitetailed deer and feral hogs as the next biggest contributors. As a highly destructive invasive exotic species, feral hogs are the natural choice for intensive management. White-tailed deer are already highly managed in Texas. As arguably the most important game species in the state, population reduction is sometimes undesirable. Overabundant 
populations of white-tailed deer contribute more E. coli into the floodplain and cause damage to vegetative communities thus increasing $E$. coli transmission into water bodies (Chapter IV). In these scenarios population reduction is highly desired. Meso-mammals populations can be controlled, but high effort, cost, and potential impact on ecosystem function make it difficult. Wildlife management to improve water quality must be undertaken with great caution. Other point and non-point sources must be addressed first or in conjunction with wildlife management and the greater impacts on the ecosystem must be taken into account.

In Chapter IV, I determined the (1) parameters important to E. coli load in the floodplain and (2) potential E. coli load in the Cedar Creek floodplain under different management scenarios. Although all of the tested parameters remain in desperate need of further research, my sensitivity analyses indicated that $E$. coli survival is especially important. Relatively simple studies that determine defecation rates and E. coli survival in different fecal morphologies would drastically improve available knowledge.

My analysis of potential management strategies illustrated the large importance that raccoons play in $E$. coli deposition. They overwhelmingly determined wildlife $E$. coli contribution during my simulations. These results are in need of scrutiny, due to the likely variability of other parameters in other locations (e.g., spatial data). I argue that reduction of feral hogs is the most practical wildlife management strategy in improving water quality. Feral hogs are invasive exotics that can be theoretically controlled to the point of eradication. Without intensive and consistent management, hogs have the ability to increase in numbers rapidly thus enlarging their potential impact on water 
quality in the future. I found that reduction of deer herds would decrease the E. coli load in the watershed, though the deer population does not appear overabundant. Mesomammals are likely untenable management targets. A broad-based management strategy targeting multiple meso-mammal species would be required to control species contributions. Additionally, impacts on local ecology are unpredictable and likely undesired. Control of meso-mammal over-population is advisable for multiple reasons, with water quality concerns now adding to the argument.

The reduction of wildlife's contribution of fecal pollution into water bodies is greatly impacted by habitat management strategies. For instance, over-grazing by cattle can greatly reduce vegetation cover and increase soil impermeability; thereby increasing E. coli transmission into the water body. Brush encroachment can decrease vegetative cover and increase overland flow and erosion problems. Wildlife feeders (e.g., deer feeders) tend to attract a variety of species (e.g., deer, feral hogs, raccoons). Normal placement of these feeders is in riparian areas to take advantage of the abundance of target species; however, the cost of this activity is an unnatural abundance of species attracted to near-stream areas. I would recommend that habitat management enter into the consciousness of all managers seeking to reduce fecal pollution into water bodies. On a large scale, preservation or conservation of vegetative communities and restoration of animal communities and behaviors, would likely decrease wildlife contribution of $E$. coli to water bodies. 


\section{LITERATURE CITED}

Acevedo, P., J. Vicente, U. Hōfle, J. Cassinello, F. Ruiz-Fons, C. Gortazar. 2006. Estimation of European wild boar relative abundance and aggregation: a novel method in epidemiological risk assessment. Epidemiology and Infection 134:19.

Arnqvist, G., and D. Wooster. 1995. Meta-analysis: synthesizing research findings in ecology and evolution. Trends in Ecology and Evolution 10:236-240.

Atwill, E. R., R. Phillips, and F. Rulofson. 2003. Estimating environmental loading rates of the waterborne pathogenic protozoa Cryptosporidium parvum, in certain domestic and wildlife species in California. University of California Davis:

Sierra Foothill Research and Extension Center, Davis, California, USA.

Bach, S. J., K. Stanford, and T. A. McAllister. 2005. Survival of Escherichia coli O157:H7 in feces from corn- and barley-fed steers. FEMS Microbiology $252: 25-33$.

Blackwell, B. F., T. W. Seamans, R. J. White, Z. J. Patton, R. M. Bush, and J. D. Cepek. 2004. Exposure time of oral rabies vaccine baits relative to baiting density and raccoon population density. Journal of Wildlife Diseases 40: 222-229.

Booth, A. M., C. Hagedorn, A. K. Graves, S. C. Hagedorn, and K. H. Mentz. 2003. Sources of fecal pollution in Virginia's Blackwater River. Journal of Environmental Engineering 129:647-662.

Brannan, K. M., T. A. Dillaha, M. L. Wolfe, S. Shah, S. Mostaghimi, C. D. Heatwole, 
M. Al-Smadi, and J. Miller. 2001. Big Otter River fecal coliform TMDL: a case study. ASAE Meeting Paper Number: 01-2067, American Association of Agricultural and Biological Engineers, St. Joseph, Michigan, USA.

Brittingham, M. C., S. A. Temple, and R. M. Duncan. 1988. A survey of the prevalence of selected bacteria in wild birds. Journal of Wildlife Diseases 24:299-307.

Burnham, K. P., and D. R. Anderson. 1998. Model selection and inference: a practical information-theoretic approach. Springer-Verlag Press, New York, New York, USA.

Burnham, K. P., D. R. Anderson, G. C. White, C. Brownie, and K. H. Pollock. 1987. Design and analysis methods for fish survival experiments based on releaserecaptures. American Fisheries Society Monograph 5.

Casarez, E. A., S. D. Pillai, J. B. Mott, M. Vargas, K. E. Dean, and G. D. Di Giovanni. 2007. Direct comparison of four bacterial source tracking methods and use of composite data sets. Journal of Applied Microbiology 103:350-364.

Claridge, A. W., G. Mifsud, J. Dawson, and M. J. Saxon. 2004. Use of infrared digital cameras to investigate the behaviour of cryptic species. Wildlife Research $31: 645-650$.

Collins, R., and K. Rutherford. 2003. Modelling bacterial water quality in streams draining pastoral land. Water Research 38:700-712.

Cox, P., M. Griffith, M. Angles, D. Deere, and C. Ferguson. 2005. Concentrations of pathogens and indicators in animals feces in the Sydney watershed. Applied and Environmental Microbiology 71:5929-5934. 
Culver, T. B, Y. Jia, R. Tikoo, and J. Simsic. 2002. Development of the total maximum daily load (TMDL) for fecal coliform bacteria in Moore's Creek, Albemarle County, Virginia. Virginia Department of Environmental Quality, Richmond, USA.

Dewulf, A., M. Craps, R. Bouwen, T. Taillieu, and C. Pahl-Wostl. 2005. Integrated management of natural resources: dealing with ambiguous issues, multiple actors, and diverging frames. Water Science and Technology 52:115-124.

Dobson, A., and J. Foufopoulos. 2001. Emerging infectious pathogens of wildlife. Philosophical Proceedings of the Royal Society of London 356:1001-1012.

Faulhaber, C. A. 2003. Updated distribution and reintroduction of the lower keys marsh rabbit. Thesis, Texas A\&M University, College Station, USA.

Fischer, J. R., T. Zhao, M. P. Doyle, M. R. Goldberg, C. A. Brown, C. T. Sewell, D. M. Kavanaugh, and C. D. Bauman. 2001. Experimental and field studies of Escherichia coli O157:H7 in white-tailed deer. Applied and Environmental Microbiology 67:1218-1224.

Fisher, D. S., J. L. Steiner, D. M. Endale, J. A. Stuedemann, H. H. Schomberg, A. J. Franzluebbers, and S. R. Wilkinson. 2000. The relationship of land use practices to surface water quality in the Upper Oconee watershed of Georgia. Forest Ecology and Management 128:39-48.

Gehrt, S. D., D. E. Clark, and E. K. Fritzell. 1997. Population dynamics and ecology of Virginia opossums in southern Texas. The Southwestern Naturalist 42:170-176.

Gleick, P. H. 2006. Water conflict chronology. Pacific Institute for Studies in 
Development, Environment, and Security, Oakland, California, USA. Available from www.worldwater.org/conflictchronology.pdf (Accessed 12 December 2006).

Graves, H. B. 1984. Behavior and ecology of wild and feral swine (Sus scrofa). Journal of Animal Science 58:482-492.

Guan, S., R. Xu, S. Chen, J. Odumeru, and C. Gyles. 2002. Development of a procedure for discriminating among Escherichia coli isolates from animal and human sources. Applied and Environmental Microbiology 68:2690-2698.

Gurevitch, J., L. L. Morrow, A. Wallace, and J. S. Walsh. 1992. A meta-analysis of competition in field experiments. American Naturalist 140:539-572.

Haftendorn, H. 2000. Water and international conflict. Third World Quarterly 21:51-68. Hagedorn, C., S. L. Robinson, J. R. Filtz, S. M. Grubbs, T. A. Angier, and R. B. Reneau, Jr. 1999. Determining sources of fecal pollution in a rural Virginia watershed with antibiotic resistance patterns in fecal Streptococci. Applied and Environmental Microbiology 65:5522-5531.

Hamilton, M. J., T. Yan, M. J. Sadowsky. 2006. Development of goose- and duckspecific DNA markers to determine sources of Escherichia coli in waterways. Applied and Environmental Microbiology 72:4012-4019.

Hedges, L. V., J. Gurevitch, and P. S. Curtis. 1999. The meta-analysis of response ratios in experimental ecology. Ecology 80:1150-1156.

Hone, J., R., R. Pech, and P. Yip. 1992. Estimation of the dynamics and rate of 
transmission of classical swine fever (hog cholera) in wild pigs. Epidemiology and Infection 108:377-386.

Hopkins, D. D., and R. B. Forbes. 1979. Size and reproductive patterns of the Virginia opossum in northwestern Oregon. The Murrelet 60:95-98.

Jacobson, H. A., J. C. Kroll, R. W. Browning, B. H. Koerth, and M. H. Conway. 1997. Infrared cameras for censusing white-tailed deer. Wildlife Society Bulletin $25: 547-556$.

Jeganathan, P., R. E. Green, C. G. R. Bowden, K. Norris, D. Pain, and A. Rahmani. 2002. Use of tracking strips and automatic cameras for detecting critically endangered Jourdan's coursers Rhinoptilus bitorquatus in scrub jungle in Andhra Pradesh, India. Oryx 36:182-188.

Kaller, M. D., J. D. Hudson III, E. C. Achberger, and W. E. Kelso. 2007. Feral hog research in western Louisiana: expanding populations and unforeseen consequences. Human-Wildlife Conflicts 1:168-177.

Karanth, K. U., and J. D. Nichols. 1998. Estimation of tiger densities in India using photographic captures and recaptures. Ecology 79:2852-2862.

Kasparian, M. A., E. C. Hellgren, S. M. Ginger, and L. P. Levesque, J. E. Clark, D. L. Winkelman, and D. M. Engle. 2004. Characteristics of Virginia opossum in the Cross Timbers during raccoon reduction. American Midland Naturalist $151: 154-163$

Kellert, S. R. 1996. The value of life. Island Press, Washington, D.C., USA. 
Kennedy, J. J., and J. W. Thomas. 1995. Managing natural resources as social value. Pages 311-322 in R. L. Knight and S. F. Bates, editors. A new century for natural resource management. Island Press, Washington, D.C., USA.

Krebs, C. J. 1999. Ecological Methodology. Addison-Welsey, Menlo Park, California, USA.

Lamendella, R., J. W. Santo Domingo, D. B. Oerther, J. R. Vogel, and D. M. Stoeckel. 2006. Assessment of fecal pollution sources in a small northern-plains watershed using PCR and phylogenetic analyses of Bacteroidetes 16S rRNA gene. FEMS Microbial Ecology 59:651-660.

Lawson, L. 2001. Fecal coliform TMDL for Mountain Run (Culpeper County, VA). Virginia Department of Environmental Quality, Richmond, USA.

Levesque, B., P. Brousseau, P. Simard, E. Dewailly, M. Meisels, D. Ramsay, and J. Joly. 1993. Impact of the ring-billed gull (Larus delawarensis) on the microbiological quality of recreational water. Applied and Environmental Microbiology $59: 1228-1230$.

Loch, R. J. 2000. Effects of vegetation cover on runoff and erosion under simulated rain and overland flow on a rehabilitated site on the Meandu Mine, Tarong, Queensland. Australian Journal of Soil Restoration, 38:299-312.

Lopez, R. R. 2001. Population ecology of Florida Key deer. Dissertation, Texas A\&M University, College Station, USA.

Lopez, R. R., M. E. P. Vieira, N. J. Silvy, P. A. Frank, S. W. Whisenant, and D. A. 
Jones. 2003. Survival, mortality, and life expectancy of Florida Key deer. Journal of Wildlife Management 67:34-45.

Lopez, R. R., N. J. Silvy, J. D. Sebesta, S. D. Higgs, and M. W. Salazar. 1998. A portable drop net for capturing urban deer. Proceedings of the Annual Conference of the Southeast Association of Fish and Wildlife Agencies 52:206209.

Lotze, J., and S. Anderson. 1979. Procyon lotor. Mammalian Species 119:1-8.

Main, M. B., and L. W. Richardson. 2002. Response of wildlife to prescribed fire in southwest Florida pine flatwoods. Wildlife Society Bulletin 30:213-221.

Mallin, M. M., K. E. Williams, E. C. Esham, and R. P. Lowe. 2000. Effects of human development on bacteriological water quality in coastal watersheds. Ecological Applications 10:1047-1056.

Mapston, M. E. 2007. Feral hogs in Texas. Agrilife Extension B-6149 03-07, Texas A\&M University, College Station, USA.

MapTech, Inc. 2002. Fecal coliform TMDL (total maximum daily load) development for Catoctin Creek impairments, Virginia. Virginia Department of Environmental Quality, Richmond, USA

Maryland Department of the Environment (2004). Total maximum daily loads of fecal coliform for Church Creek in the Little Choptank River basin in Dorchester County, Maryland. Maryland Department of the Environment, Baltimore, USA. Maryland Department of the Environment. 2005. Total maximum daily loads of fecal 
coliform for the restricted shellfish harvesting portion of the Corsica River in Queen Anne's County, Maryland. Maryland Department of the Environment, Baltimore, USA.

McCleery, R. A., G. W. Foster, R. R. Lopez, M. J. Peterson, D. J. Forrester, and N. J. Silvy. 2005. Surveys of raccoons on Key Largo, Florida, USA, for Baylisascaris procyonis. Journal of Wildlife Diseases 41:250-252.

McCullough, D. R. 1982. White-tailed deer pellet-group weights. The Journal of Wildlife Management 3:829-832.

McKinney, M. L. 2002. Urbanization, biodiversity, and conservation. BioScience $52: 883-890$.

Meays, C. L., K. Broersma, R. Nordin, and A. Mazumder. 2005. Survival of Escherichia coli in beef cattle fecal pats under different levels of solar exposure. Rangeland Ecology and Management 58:279-283.

Meyer, K. J., C. M. Appletoft, A. K. Schwemm, J. C. Uzoigwe, and E. J. Brown. 2005. Determining the source of fecal contamination in recreational waters. Journal of Environmental Health 68: 25-30.

Michael, E. D. 1965. Movements of white-tailed deer on the Welder Wildlife Refuge. The Journal of Wildlife Management 29:44-52.

Miller, A. 2004. Total maximum daily load development for fecal coliform bacteria Lower Saluda River and tributaries stations: Lower Saluda S-149, Twelve Mile Creek S-294, Kinley Creek S-260 (HUC 03050109-210). South Carolina Department of Health and Environmental Control, Columbia, USA. 
Millican, J., and L. Hauck. 2008. Final draft technical support document segments 0806, 0841, 0822, 0805 of the Trinity River bacteria TMDL. Texas Commission on Environmental Quality, Austin, USA.

Morrison, M. L. 2002. Wildlife restoration: techniques for habitat analysis and animal monitoring. Island Press, Washington, D.C., USA.

Morrison, M. L., W. M. Block, M. D. Strickland, and W. L. Kendall. 2001. Wildlife study design. Springer-Verlag Press, New York, New York, USA.

Naiman, R. J. 1988. Animal influences on ecosystem dynamics. Bioscience 38:750752.

Natural Resources Conservation Service [NRCS]. 2010. Soil data viewer. United States Department of Agriculture. Available from http://soildataviewer.nrcs.usda.gov/ (Accessed 10 April 2010).

Ohio State University Extension. 2006. Ohio livestock manure management guide. Bulletin 604. The Ohio State University, Columbus, USA.

Padia, R. 2010. Occurrence and fate of Escherichia coli from non-point sources in Cedar Creek watershed, Texas. Thesis, Texas A\&M University, College Station, USA.

Parajuli, P. B., K. R. Mankin, and P. L. Barnes. 2008. Applicability of targeting vegetative filter strips to abate fecal bacteria and sediment yield using SWAT. Agricultural Water Management 95:1189-1200.

Porter, R. A., P. E. Ginn, J. B. Dame, and E. C. Greiner. 2001. Evaluation of the 
shedding of Sarcocystis falcatula sporocysts in experimentally infected Virginia opossums (Didelphis virginiana). Veterinary Parasitology 95:313-319.

Ram, J. L., B. Thompson, C. Turner, J. M. Nechvatal, H. Sheehan, and J. Bobrin. 2007. Identification of pets and raccoons as sources of bacterial contamination of urban storm sewers using sequence-based bacterial source tracking method. Water Research 41:3605-3614.

Renter, D. G., J. M. Sargeant, S. E. Hygnstorm, J. D. Hoffman, and J. R. Gillespie. 2001. Escherichia coli in free-ranging deer in Nebraska. Journal of Wildlife Diseases 37:755-760.

Rice, N. 2005. Water quality modeling analysis for the Cedar Creek watershed. Indiana Watershed Management Section, Department of Environmental Management, Indianapolis, Indiana, USA.

Riley, S. P. D., J. Hadidian, and D. A. Manski. 1998. Population density, survival, and rabies in raccoons in an urban national park. Canadian Journal of Zoology $76: 1153-1164$.

Roberts, C. W., B. L. Pierce, A. W. Braden, R. R. Lopez, N. J. Silvy, P. A. Frank, and D. Ransom, Jr. 2005. Comparison of camera and road survey estimates for whitetailed deer. Journal of Wildlife Management 70:263-267.

Rutala, W. A., and D. J. Weber. 2008. Guideline for disinfection and sterilization in healthcare facilities, 2008. Centers for Disease Control and Prevention, Department of Health and Human Services, Atlanta, Georgia, USA.

Sawyer, T. G., R. L. Marchinton, and W. Mac Lentz. 1990. Defecation rates of female 
white-tailed deer in Georgia. Wildlife Society Bulletin 18:16-18.

Scott, L., P. McGee, J. J. Sheridan, B. Earley, and N. Leonard. 2006. A comparison of the survival in feces and water of Escherichia coli O157:H7 grown under laboratory conditions or obtained from cattle feces. Journal of Food Protection 69:6-11.

Siewicki, T. C., T. Pullaro, W. Pan, S. McDaniel, R. Glenn, and J. Stewart. 2007. Models of total and presumed wildlife sources of fecal coliform bacteria in coastal ponds. Journal of Environmental Management 82:120-132.

Silvy, N. J. 1975. Population density, movements, and habitat utilization of Key deer, Odocoileus virginianus clavium. Dissertation, Southern Illinois University, Carbondale, USA.

Solomon, E. B., S. Yaron, and K. R. Matthews. 2001. Transmission of Escherichia coli O157:H7 from contaminated manure and irrigation water to lettuce plant tissue and its subsequent internalization. Applied and Environmental Microbiology 49: $1-7$.

Somarelli, J. A., J. C. Makarewicz, R. Sia, and R. Simon. 2007. Wildlife identified as major source of Escherichia coli in agriculturally dominated BOX A1R-derived genetic fingerprints. Journal of Environmental Management 82:60-65.

Sorvillo, F., L. R. Ash, O. G. W. Berlin, J. Yatabe, C. Degiorgio, and S. A. Morse. 2002. Baylisascaris procyonis: an emerging helminthic zoonosis. Emerging Infectious Diseases 8:355-359.

Streets, B. M., and P. A. Holden. 2003. A mechanistic model of runoff-associated fecal 
coliform fate and transport through a coastal lagoon. Water Research 37:589608.

Sweitzer, R. A., D. V. Vuren, I. A. Gardner, W. M. Boyce, and J. D. Waithman. 2000. Estimating sizes of wild pig populations in the north and central coast regions of California. The Journal of Wildlife Management 64:531-543.

Teague, A., R. Karthikeyan, M. Babbar-Sebens, R. Srinivasan, and R. A. Persyn. 2009. Spatially explicit load enrichment calculation tool to identify potential E. coli sources in watersheds. Transactions of the ASABE 52:1109-1120.

Texas Parks and Wildlife Department. Post oak savannah and blackland prairie wildlife management: historical perspective. Available from http://www.tpwd.state.tx.us/landwater/land/habitats/post_oak. (Accessed 4 March 2010).

Tian, Y. Q., P. Gong, J. D. Radke, and J. Scarborough. 2002. Spatial and temporal modeling of microbial contaminants on grazing farmlands. Journal of Environmental Quality 31:860-869.

Trolle, M. 2003. Mammal survey in the southeastern Pantanal, Brazil. Biodiversity and Conservation 12:823-836.

Trolle, M., and M. Kéry. 2005. Camera-trap studies of ocelot and other secretive mammals in the northern Pantanal. Mammalia 69:405-412.

Turner, M. G., G. J. Arthaud, R. Todd Engstrom, S. J. Hejl, and J. Liu. 1995. Usefulness of spatially explicit population models in land management. Ecological Applications 5:12-16. 
U.S. Environmental Protection Agency. 2010. Better assessment science integrating point and non-point sources (BASINS). Available from http://www.epa.gov/waterscience/basins/. (Accessed 18 March 2010).

U.S. Environmental Protection Agency. 2008. List of impaired waters. Available from http://oaspub.epa.gov/tmdl/. (Assessed 28 March 2008)

Wainwright, J., A. J. Parsons, and A. D. Abrahams. 2000. Plot-scale studies of vegetation, overland flow, and erosion interactions: case studies from Arizona and New Mexico. Hydrological Processes 14:2921-2943.

Watts, D. E., I. D. Parker, R. R. Lopez, N. J. Silvy, and D. S. Davis. 2008. Distribution and abundance of endangered Florida key deer on outer islands. Journal of Wildlife Management 72:360-366.

White, G. C., and K. P. Burnham. 1999. Program MARK: survival estimation from populations of marked animals. Bird Study Supplement 46:120-138.

Whitlock, J. E., D. T. Jones, and V. J. Harwood. 2002. Identification of the sources of fecal coliforms in an urban watershed using antibiotic resistance analysis. Water Research 36:4273-4282.

Wieckowicz, R., E. G. Wilcox, and B. Ralys. 2008. Final TMDL report fecal coliform TMDL for Black Creek, WBID 1024. Florida Department of Environmental Protection, Tallahassee, USA.

Wittman Hydro Planning Associates, Inc. 2004. WHPA Salt Creek E. coli TMDL. Indiana Department of Environmental Management, Watershed Management Section, Indianapolis, USA. 
Zeckoski, R. W., B. L. Benham, S. B. Shah, M. L. Wolfe, K. M. Brannan, M. Al-Smadi, T. A. Dillaha, S. Mostaghimi, and C. D. Heatwole. 2005. BSLC: a tool for bacteria source characterization for watershed management. Applied

Engineering in Agriculture 21:879-889. 
APPENDIX A

\section{Mark}
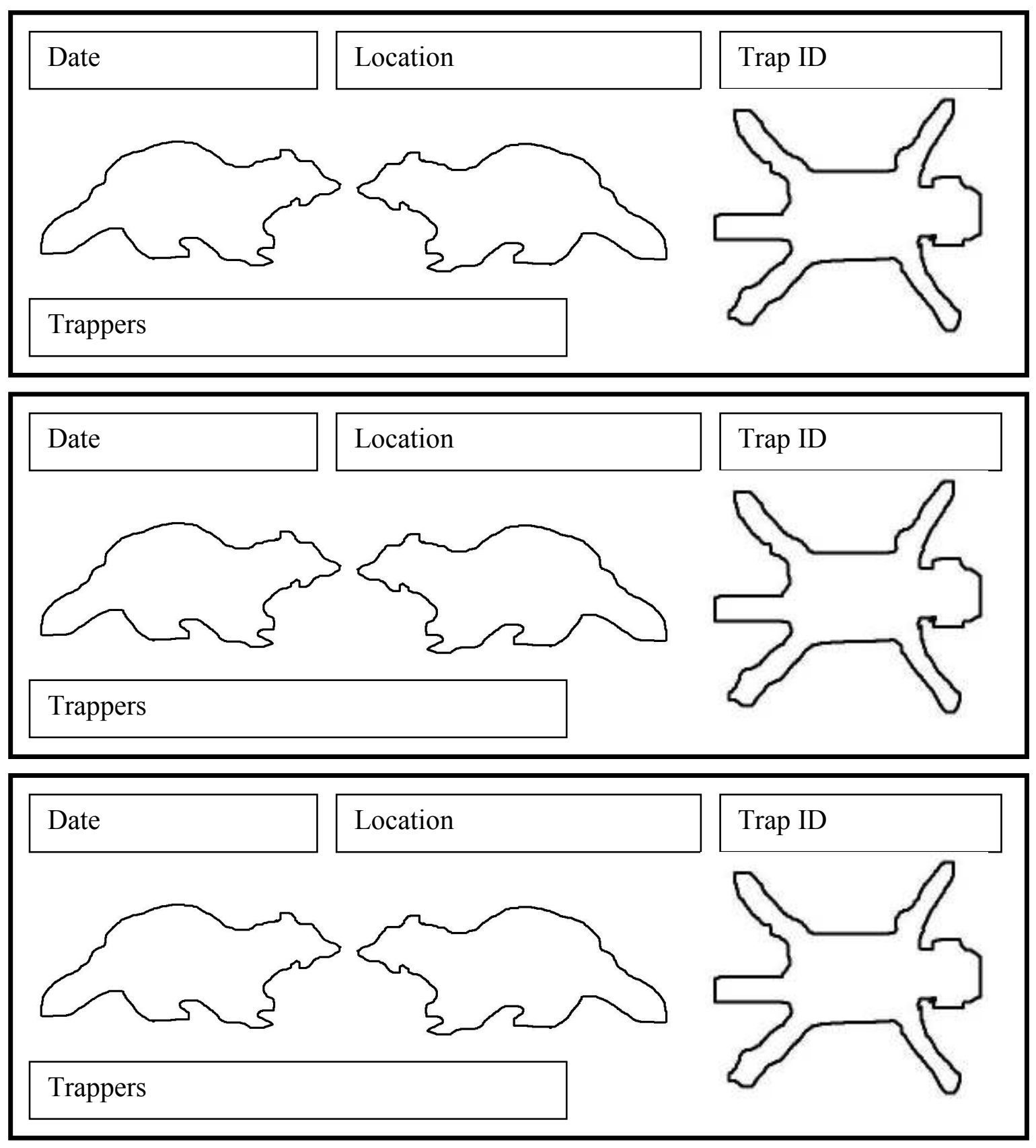
VITA

ISRAEL DAVID PARKER

\section{ADDRESS}

Department of Wildlife and Fisheries Sciences

Texas A\&M University

2258 TAMU

210 Nagle Hall

College Station, TX 77843-2258

iparker@neo.tamu.edu

\section{EDUCATION}

Doctor of Philosophy, Wildlife and Fisheries Sciences, Texas A\&M University, 2010

Master of Science, Wildlife and Fisheries Sciences, Texas A\&M University, 2006

Bachelor of Science, Fishery and Wildlife Sciences, New Mexico State University, 2002

\section{WORK EXPERIENCE}

Doctoral Research Fellow, Hispanic Leadership Program in Agriculture and Natural Resources, Texas A\&M University, 2006-2009

Field Technician, Texas A\&M University, White-tailed Deer, 2003-2004, 2007-2008

Field Technician, New Mexico State University, Black-tailed Prairie Dogs, (Summer 2003)

Field Technician, New Mexico State University, Savannah Sparrows, JanuaryMay 2003

Intern, Arizona Game and Fish Department, Sonoran Pronghorn, Summer 2001

Field Technician/Directed Studies, New Mexico State University, Gemsbok, 2001-2002 